\title{
Effects of eruption source parameter variation and meteorological dataset on tephra fallout hazard assessment: example from Vesuvius (Italy)
}

\author{
Giovanni Macedonio ${ }^{1 *}$ (D), Antonio Costa ${ }^{2}$, Simona Scollo 3 and Augusto Neri ${ }^{4}$
}

\begin{abstract}
In this study, using the tephra dispersal model HAZMAP, we investigate the effect of using different meteorological datasets and eruption source parameters on tephra fallout hazard assessment for a sub-Plinian eruption of Vesuvius, which is considered as a reference case for hazard assessment analysis. We analyze the effect of using different meteorological data, from: i) radio-sounding carried out at the meteorological station of Brindisi (Italy) between 1962 and 1976 and between 1996 and 2012, and at Pratica di Mare (Rome, Italy) between 1995 and 2013; ii) meteorological models of the National Oceanic and Atmospheric Administration (NOAA), and of the European Centre for Medium-Range Weather Forecasts (ECMWF). Furthermore, we consider the effects of perturbing reference eruptive source parameters. In particular, we vary the total mass, the total grain-size distribution, the column height, and the effective atmospheric diffusion coefficient to evaluate how these parameters affect the hazard probability maps. Moreover, the effect of the seasonal variation of the wind field and the effect of the rain on the deposit loading are considered. Results show that the parameter that mostly affects hazard maps is, as expected, the total erupted mass; furthermore, keeping constant the erupted mass, the most important control on hazard is due to the particle terminal settling velocity distribution which is a function of the total grain-size distribution, particle density and shape. Within the considered range variations, the hazard depends less on the use of different meteorological datasets, column height and effective diffusion coefficient.
\end{abstract}

Keywords: Statistical study, Meteorological datasets, Eruption source parameters, Probability maps, Vesuvius area

\section{Introduction}

Risk assessment for tephra fallout in the highly urbanized area around Vesuvius (more than 1 million people) is an important and difficult goal. The type of explosive activity may be defined on the basis of the information derived from the past behavior of the volcano, currently quiescent since 1944. The Somma strato-volcano, the oldest edifice, formed between 37 and 20 ka mainly by effusive activity (e.g. Andronico et al. 1995; Cioni et al. 2003). Recent activity of Vesuvius was characterized by different eruptive styles depending on the conditions of the

*Correspondence: giovanni.macedonio@ingv.it

1 Istituto Nazionale di Geofisica e Vulcanologia, Osservatorio Vesuviano, Via Diocleziano 328, 80124 Napoli, Italy

Full list of author information is available at the end of the article magmatic system. They ranged from Strombolian activities to sub-Plinian and Plinian eruptions (e.g. Cioni et al. 2008; Neri et al. 2008; Rolandi et al. 1993; Rosi et al. 1987; Santacroce et al. 2008; Todesco et al. 2002). The largest Plinian event is the "Pomici di Base" eruption occurred around $18 \mathrm{ka}$ (Bertagnini et al. 1998) formed a caldera that was modified after other major explosive events (Cioni et al. 1999). Other Plinian eruptions occurred at $8 \mathrm{ka}$, the "Pomici di Mercato" eruption (e.g. Aulinas et al. 2008; Mele et al. 2011); $3.8 \mathrm{ka}$, the "Pomici di Avellino" eruption (e.g. Cioni et al. 2000) and in A.D. 79, the "Pompei" eruption (e.g. Andronico and Cioni 2002; Barberi et al. 1989). In between these major eruptions, Vesuvius explosive activity was characterized by several sub-Plinian eruptions. The two most recent of these major events occurred in A.D. 472 (Rolandi et al. 2004; Rosi and Santacroce

\section{至}


1983) and in A.D. 1631 (Barberi et al. 1989; Rolandi et al. 1993; Rosi et al. 1993). Finally, the most frequent low energy activity spans from Violent Strombolian to continuous ash emission (Barberi et al. 1989; Cioni et al. 2008). Tephra fallout from all these eruptions seriously affected the Vesuvius area in the last 18,000 years (e.g. Cioni et al. 2003) but the impact of a future eruption will be substantially higher because of the intense urbanization of the area.

Macedonio et al. (1990) suggested that a shallow magma chamber at Vesuvius is currently supplied at a constant rate and an event similar to the A.D. 1631 eruption is expected. This scenario represented the "Maximum Expected Event" (MEE) at Vesuvius for a short-medium time window (Barberi et al. 1990; Cioni et al. 2003; Macedonio et al. 1990).

The first probability map for tephra fallout at Vesuvius was obtained by Barberi et al. (1990). They considered an eruption with total mass of $1-2 \times 10^{11} \mathrm{~kg}$ of tephra, wind velocity distribution obtained by the analysis of a radiosounding station located in Brindisi (Italy) in the period between 1962 and 1976, and results from a tephra dispersal model. This study allowed the evaluation of the extent of the area around Vesuvius more likely to be affected by roof collapses, which is mainly located in the east sector of the volcano. New assessment of tephra fallout was carried out by Cioni et al. (2003) who evaluated the conditional probability of a mass loading greater than a given threshold, considering an event with total mass equal to $5 \times 10^{11} \mathrm{~kg}$, column heights spanning from 12 to $22 \mathrm{~km}$, the same wind velocity profiles recorded at Brindisi, and four different total grain-size distributions. Other probability maps for different eruption scales, such as Plinian, sub-Plinian, and Violent Strombolian events, were computed by Macedonio et al. (2008) with the dispersal model HAZMAP (Macedonio et al. 2005), using NCEP/NCAR re-analysis wind data from 1968 to 2003 . These authors highlighted the different impact of those events with respect to the MEE.

Tephra transport and dispersal models of various types have been extensively used for hazard assessment at several volcanoes around the world (e.g. Barberi et al. 1990; Barsotti et al. 2015; Bonadonna et al. 2002; 2005; Bonasia et al. 2011; 2012; Capra et al. 2008; Costa et al. 2009; Hill et al. 1998; Jenkins et al. 2015; Macedonio et al. 2008; Scaini et al. 2012; Scollo et al. 2008; 2013; Sieron et al. 2014). However, the eruption source parameters of the considered reference scenario are commonly kept fixed an their variability and uncertainty are rarely taken into account. Moreover, meteorological data usually come from a single database.

In this paper we present the main outcomes of a detailed investigation of the effects of meteorological datasets and key eruption source parameters on the fallout hazard maps for the reference scenario adopted for the Emergency Plan of Vesuvius (DPC 2001; 2015; Regione Campania 2015). The goal is to highlight the role of the uncertainty and the natural variability on the probability maps commonly used for hazard assessment.

\section{Method}

In order to analyze the effect that the use of different wind datasets and the variation of the main eruptive source parameters have on the fallout hazard maps, we used the HAZMAP model (Macedonio et al. 2005). The HAZMAP model (freely available at http: // datas im . ov.ingv.it) is based on the solution of a simplified 2D equations of diffusion, transport and sedimentation of small particles, describing the dispersion of tephra generated by a volcanic convective column. The HAZMAP code was previously used to produce hazard maps at Vesuvius (Macedonio et al. 2008) and Campi Flegrei (Costa et al. 2009).

The investigation of the effects of tephra transport model on the hazard maps is outside the scope of this work, which is mainly focused on the analysis of the effects of the meteorological and the volcanological source parameters. In a previous work, Scollo et al. (2008) found that, at Etna volcano, larger differences between the output of tephra transport models are related to topographic effects, which strongly affect the dispersal of fine particles for column heights lower than $12 \mathrm{~km}$; however these difference decrease in simulating higher eruption columns (Scollo et al. 2008). With respect to Scollo et al. (2008), who deal with a sensitivity analysis of tephra transport at Etna for small to moderate eruptions, the present work is focused on a sub-Plinian eruption at Vesuvius.

Here, we considered three different meteorological radio-soundings datasets and three reanalysis models, a range of total mass from $10^{11}$ to $10^{12} \mathrm{~kg}$, effective atmospheric (horizontal) diffusion coefficients from 1000 $10,000 \mathrm{~m} / \mathrm{s}^{2}$, eruption column height from $14-22 \mathrm{~km}$, and a few different total grain-size distribution. The effects of these variations were assessed on the area having probability greater than $5 \%$ of exceeding a given deposit loading (e.g. 300, 500 and $1000 \mathrm{~kg} / \mathrm{m}^{2}$ ). The other considered input parameters are described below.

\section{Meteorological dataset}

We performed a statistical analysis of wind speeds and directions in the Vesuvius area using data obtained from different datasets derived from radio-sounding stations and from reanalysis. Radio-sounding launches are routinely performed by the Aeronautica Militare (the Italian Air-Force); these data can be downloaded from the web-site of the University of Wyoming (USA) or the NOAA data center either in ASCII or NetCDF formats 
(Pincus and Rew 2010; Rew et al. 2010). Our investigation considered the following meteorological data sets:

i) radio-soundings at Brindisi station, about $300 \mathrm{~km}$ East of Vesuvius (here named BRIN) between 1962 and 1976. This dataset consists in 3125 observations (some records are missing).

ii) radio-soundings at Brindisi (LIBR station) in the period between 1 July 1996 and 31 December 2012. This dataset consists of 18,482 records. Only records containing data between ground level and $25,000 \mathrm{~m}$ above sea level, and with more than 8 data in this altitude range, were selected for this work, resulting in a dataset containing 12,788 records.

iii) radio-soundings at Pratica di Mare, Rome, about $190 \mathrm{~km}$ North-West of Vesuvius (LIRE station) in the period between 1 November 1995 and 21 December 2013. This dataset consists of 21211 records. Only records containing data between ground level and $25,000 \mathrm{~m}$ above sea level, and with more than 8 data in this altitude range, were selected for this work, resulting in a dataset containing 14,976 records.

iv) daily average data from the NOAA NCEP/NCAR Reanalysis 1 (NOAA1, 7305 records) model (Kalnay et al. 1996), spatial resolution $2.52^{\circ} \times 2.52^{\circ}$, in the period between 1991 and 2010, available in NetCDF format.

v) 6-h averaged data from the global model of NOAA-CIRES 20th Century (NOAA2, 29,220 records), spatial resolution $2^{\circ} \times 2^{\circ}$, between 1991 and 2010, available in the NetCDF format (Compo et al. 2006; Compo et al. 2011).

vi) 6-h averaged data of the global model ECMWF ERA-Interim (ERAI, 29,220 records), spatial resolution $0.75^{\circ} \times 0.75^{\circ}$, between 1991 and 2010 , available in GRIB format (Berrisford et al. 2011).

For all the reanalysis datasets, the nearest points to Naples of the global grids, were considered as representative of the entire area. Table 1 describes the main features of the meteorological datasets used in this study. For each dataset the coordinates of the station (or point of the reanalysis grid), the distance from the Vesuvius, the selected period, the acquisition frequency and the distance between the vertical layers are reported. Data acquired at different pressure levels are re-interpolated at horizontal layers of thickness $\Delta Z$ (see Table 1). Figures 1, 2, and 3 report polar diagrams of different dataset from ground up to $25-26 \mathrm{~km}$ above sea level. However, in the tephra transport simulations, the wind field above the maximum height of the volcanic column was not considered.

Figures 1 and 2 show the polar diagrams of the different winds datasets. For tephra dispersal simulations wind data are averaged over horizontal layers $500 \mathrm{~m}$ thick; however, for sake of simplicity, the figures show data averaged over thicker layers $(4-6 \mathrm{~km}$ for the BRIN station and $5 \mathrm{~km}$ for the others).

Figure 1 shows the polar diagrams of wind direction and intensity at the Brindisi station (BRIN), recorded in the period between 1962 and 1976, averaged on different horizontal layers $4-6 \mathrm{~km}$ thick. The plots show the direction towards which the wind blows (not the direction of provenance). These data were previously used by Barberi et al. (1990) and Macedonio et al. (1990) for the estimation of the fallout hazard zone a Vesuvius.

Figure 2 shows the polar diagrams of the winds, averaged on different horizontal layers $5 \mathrm{~km}$ thick, for the LIBR, LIRE, NOAA1, NOAA2 and ERAI datasets used in the present work. Again, here, the plots show the direction towards which the wind blows. A comparison between the plots shows no major differences among the datasets.

Wind direction and speed show a moderate seasonal variation, similar to that described by Costa et al. (2009). A statistics on this effect is reported in Fig. 3 for the ECMWF ERA-Interim (ERAI) dataset. The other datasets do not show significant difference with respect the ECMWF dataset.

\section{Total mass}

The total erupted mass is the most important input parameter having a first order effect. The estimation of the total mass is commonly derived by field data analysis (Bonadonna and Costa 2012; Bonadonna and Houghton 2005; Pyle 1989) or by best-fit procedure (Bonasia et al. 2010; 2012; Connor and Connor 2006;

Table 1 Meteorological datasets used in this study

\begin{tabular}{|c|c|c|c|c|c|}
\hline Dataset & Coordinates & Distance & Period & Freq. & $\Delta \mathrm{Z}$ \\
\hline Radio-sounds BRIN & $17.95^{\circ} \mathrm{E}, 40.66^{\circ} \mathrm{N}$ & $300 \mathrm{~km}$ & $1962-1976$ & daily & $2000 \mathrm{~m}$ \\
\hline Radio-sounds LIBR & $17.95^{\circ} \mathrm{E}, 40.66^{\circ} \mathrm{N}$ & $300 \mathrm{~km}$ & $1.7 .1996-31.12 .2012$ & $\approx 6 \mathrm{~h}$ & $500 \mathrm{~m}$ \\
\hline Radio-sounds LIRE & $12.45^{\circ} \mathrm{E}, 41.66^{\circ} \mathrm{N}$ & $300 \mathrm{~km}$ & $1.11 .1995-21.12 .2013$ & $\approx 6 \mathrm{~h}$ & $500 \mathrm{~m}$ \\
\hline NCEP-NCAR Rean. I & $15.00^{\circ} \mathrm{E}, 40.00^{\circ} \mathrm{N}$ & $100 \mathrm{~km}$ & $1.1 .1991-31.12 .2010$ & daily & $500 \mathrm{~m}$ \\
\hline NOAA-CIRES Rean. II & $14.00^{\circ} \mathrm{E}, 40.00^{\circ} \mathrm{N}$ & $100 \mathrm{~km}$ & $1.1 .1991-31.12 .2010$ & $6 \mathrm{~h}$ & $500 \mathrm{~m}$ \\
\hline ECMWF ERA-Interim & $14.25^{\circ} \mathrm{E}, 40.50^{\circ} \mathrm{N}$ & $40 \mathrm{~km}$ & $1.1 .1991-31.12 .2010$ & $6 \mathrm{~h}$ & $500 \mathrm{~m}$ \\
\hline
\end{tabular}




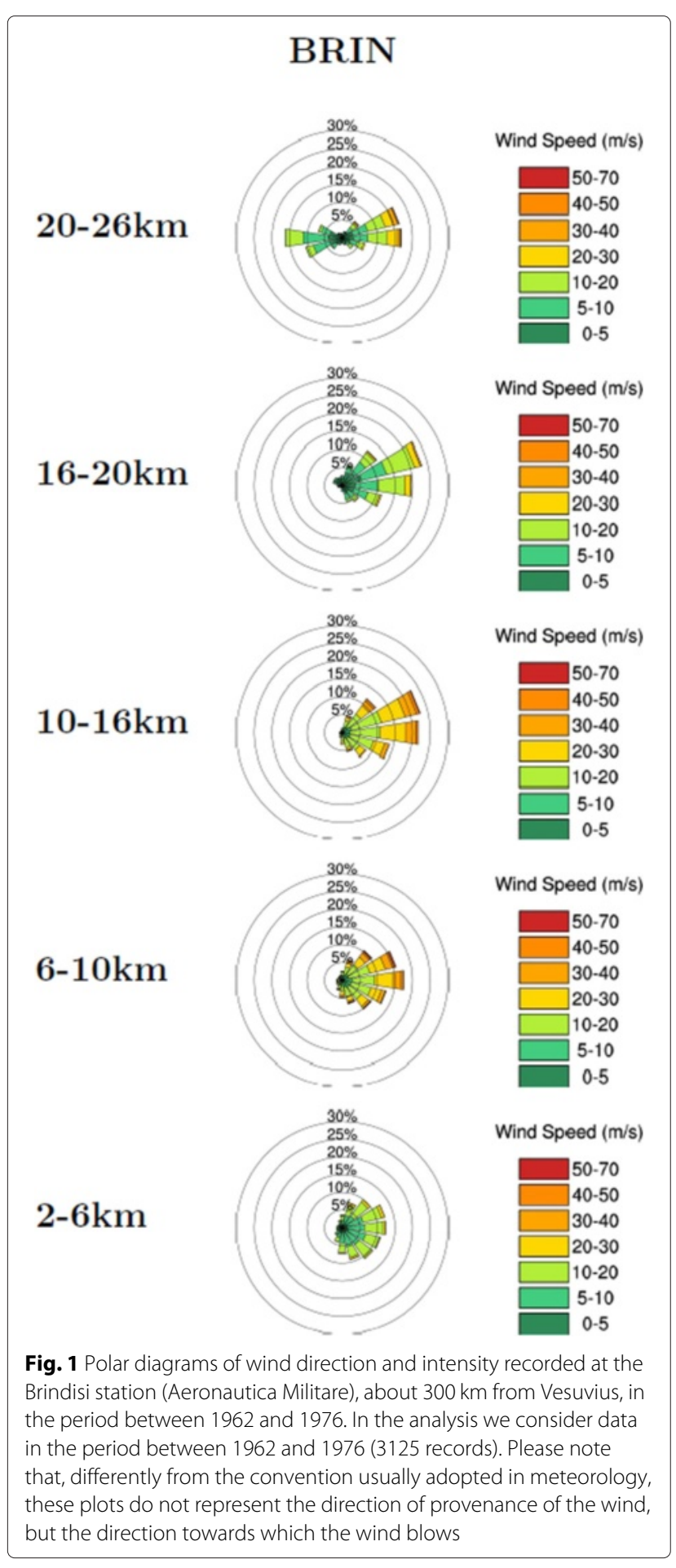

Costa et al. 2009; Pfeiffer et al. 2005; Scollo et al. 2008). Keeping fixed the other parameters, the effect of the total mass on the deposit loading, neglecting or simplifying other non-linear phenomena (e.g. the aggregation process, the variability of the wind, etc.), follows a linear relationship.
A total mass of $2 \times 10^{11} \mathrm{~kg}$ was used by Barberi et al. (1990) for assessing volcanic hazard from sub-Plinian eruptions at Vesuvius. This value derived from an estimate of the mass erupted during the main fallout phase of the Vesuvius A.D. 1631 sub-Plinian eruption obtained by Rosi et al. (1993), who found values in the range $4.5 \times 10^{10}$ and $1.35 \times 10^{11} \mathrm{~kg}$, using the method of deposit thinning. However this kind of estimation can have a large uncertainty, depending on the quality and spatial distribution of the data, up to a factor of four (Bonadonna and Costa 2012).

Moreover, the area with probability greater than a given value (e.g. $5 \%$ ) of loading (e.g. $300 \mathrm{~kg} / \mathrm{m}^{2}$ ) does not follow a linear relationship for wide ranges of the total erupted mass.

In this paper we use, as reference, the same total mass adopted by Cioni et al. (2003), who proposed a value of $5 \times 10^{11} \mathrm{~kg}$ as representative of sub-Plinian eruptions at Vesuvius. This value was also adopted by the Italian Department of Civil Protection for the reference scenario at Vesuvius (DPC 2012). Moreover, we performed a sensitivity analysis on the extension of the hazard zone by varying the total mass between $10^{11}$ and $10^{12} \mathrm{~kg}$, in agreement with the corresponding volume range proposed by Cioni et al. (2008) for the sub-Plinian (type I) eruptions.

\section{Total grain-size distribution}

The Total Grain Size Distribution (TGSD) is very difficult to estimate (e.g. Bonadonna et al. 2015). The TGSD is usually estimated from data obtained from the grainsize analysis of samples collected in several places where the thickness (or mass) is also known. The TGSD may be evaluated using weighted average based on the isomasses (Carey and Sigurdsson 1982), on statistical methods (Bonadonna and Houghton 2005) or using best-fit techniques (e.g. Bonasia et al. 2010; Costa et al. 2012; 2014; Volentik et al. 2010). However, depending on the quality of tephra sampling, the TGSD may have large uncertainties (Barsotti et al. 2010; Bonadonna and Houghton 2005; Bonadonna et al. 2015). Note also that a high percentage of fine particles (up to $50 \%$ Rose and Durant 2009) may fall as aggregates and this phenomenon is often not considered in the analysis of probability maps. Due to the lack of specific studies, the TGSD of Vesuvius has typically been considered similar to the TGSD reconstructed for the 79 AD eruption (e.g. Barberi et al. 1990; Macedonio et al. 1988; 2008). During this eruption, magma fragmentation and juvenile/lithic ratio changed with time (i.e. between the "White" and "Gray" phases). Macedonio et al. (1988) used the TGSD of the "Gray" phase as derived from the analysis of the deposit of the pyroclastic flow associated to the $79 \mathrm{AD}$ eruption. The TGSD of the "White" phase was assumed to have the same TGSD of the "Gray" phase 


\begin{tabular}{|c|c|c|c|c|c|c|}
\hline & LIBR & LIRE & NOAA1 & NOAA2 & \multicolumn{2}{|l|}{ ERAI } \\
\hline $20-25 \mathrm{~km}$ & $\left(\frac{105}{55}\right)$ & -5 & 55 & $(-5)$ & 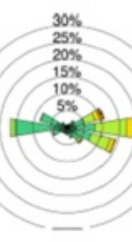 & 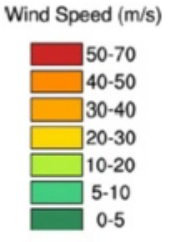 \\
\hline $15-20 \mathrm{~km}$ & C & 8 & & & & 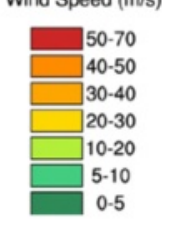 \\
\hline $10-15 \mathrm{~km}$ & \& & 2. & & & $5 \%$ & 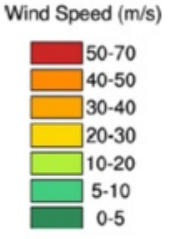 \\
\hline $5-10 \mathrm{~km}$ & 5 & 55 & & & - & 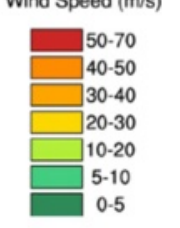 \\
\hline $0-5 \mathrm{~km}$ & $\begin{array}{l}105 \\
5^{2} \\
7\end{array}$ & 85: & & & & 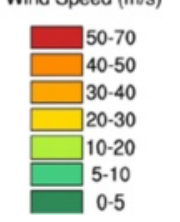 \\
\hline $\begin{array}{l}\text { Fig. } 2 \text { Compari } \\
\text { at Brindisi statio } \\
\text { di Mare (Rome, } \\
\text { NCEP/NCAR Rea } \\
\text { from NOAA/CIR } \\
29,220 \text { records); } \\
6 \text { h averages, } 29 \\
\text { direction of pro }\end{array}$ & $\begin{array}{l}\text { tween the } p \\
300 \mathrm{~km} \text { from } \\
\mathrm{km} \text { form Ve } \\
\text { is } 1 \text { (Kalnay e } \\
\text { th Century Re } \\
\text { data from th } \\
\text { ecords). Plea } \\
\text { ce of the wir }\end{array}$ & $\begin{array}{l}\text { ns of wind } \\
\text { etween } 1 \mathrm{~J} \\
\text { on betweer } \\
\text { between } 19 \\
\text { Compo et a } \\
\text { ra Interim d } \\
\text { t, differently } \\
\text { direction to }\end{array}$ & $\begin{array}{l}\text { and intensity o } \\
\text { nd } 31 \text { Decemb } \\
\text { nber } 1995 \text { and } \\
\text { at } 15 \mathrm{E}, 40 \mathrm{~N}(\approx \\
\text { 111) between } \\
\text { rrisford et al. } 2 \\
\text { convention us } \\
\text { ich the wind b }\end{array}$ & $\begin{array}{l}\text { nt meteorolo } \\
\text { (12,788 reco } \\
\text { mber } 2013 \text { ( } \\
\text { rom Vesuvius } \\
10 \text { at } 14 \mathrm{E}, 40 \\
\text { ween } 1991- \\
\text { opted in met }\end{array}$ & $\begin{array}{l}\text { ets. LIBR: r. } \\
\text { adio-soun } \\
\text { ords); NOO } \\
\text { ages, } 7,30 \\
\text { m from Ve } \\
\text { 25E,40.5N } \\
\text { hese plot }\end{array}$ & $\begin{array}{l}\text { ndings recorded } \\
\text { orded at Pratica } \\
\text { from the } \\
\text { ); NOAA2: data } \\
\text { h averages, } \\
\text { from Vesuvius, } \\
\text { epresent the }\end{array}$ \\
\hline
\end{tabular}

but with a lower proportion of lithic. Because of the lack of data, the TGSD of smaller scale sub-Plinian eruptions was assumed to be the same of the 79 AD Plinian eruption but with a different juveniles/lithics ratio (Macedonio et al. 1990).

In this work we considered the TGSD for Plinian and Sub-Plinian eruptions of Macedonio et al. (2008), and converted the TGSD to settling velocity distribution, as described below.

\section{Particle density}

An analysis of particle types characterizing the TGSD of the Vesuvius 79 A.D. eruption can be found in Macedonio et al. (1988). Lithic particles usually show constant density whereas juvenile particles show a density variable with the size (e.g. lower density for particles of greater size) due to the presence of larger bubbles inside larger clasts. The variation of the density of juvenile particles with their size was analyzed by different authors (e.g. Bonadonna and Phillips 2003; Walker 1971). For sake of consistency, we used the same density variation as Macedonio et al. (1990), who adopted a simplified function for describing the particle density variations. However, as shown by Pfeiffer et al. (2005), particle density has a second order effect on the settling velocity with respect to the particle dimensions. 


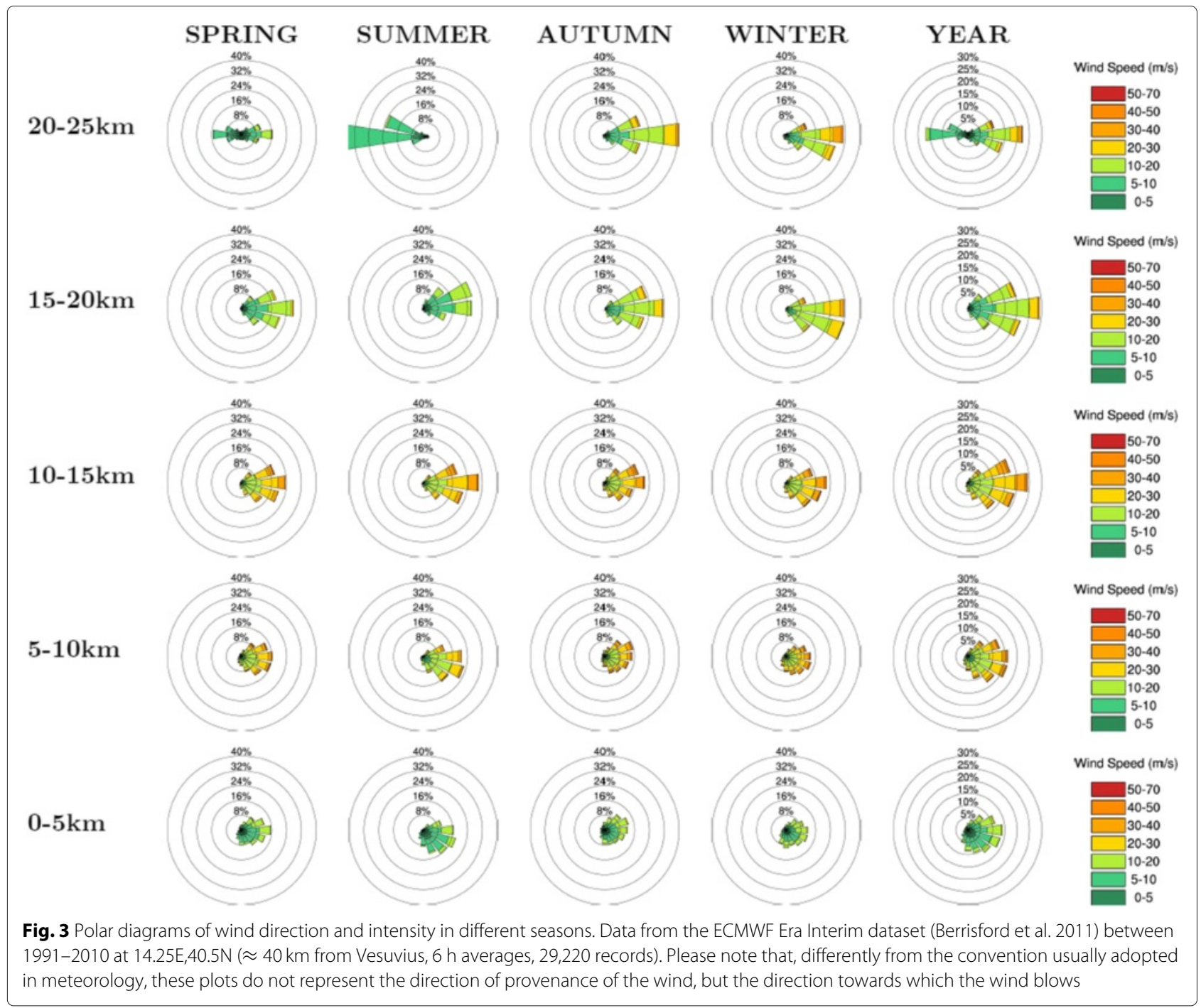

\section{Particle aggregation}

It is well known that smaller particles (diameter ranging from sub-micron to tens of micron) fall as aggregates with greater settling velocity than the single particles and deposit in areas much closer to the volcano (Bonadonna et al. 2002; Carey and Sigurdsson 1982; Cornell et al. 1983; James et al. 2003). A few models aimed at describing the aggregation processes, with different degree of complexity, have been proposed (Armienti et al. 1988; Bonadonna et al. 2002; Cornell et al. 1983; Costa et al. 2010; Folch et al. 2010; Macedonio et al. 1988). One of the simplest and more commonly used approach was suggested by Cornell et al. (1983) in order to reproduce field observations of the Campanian Ignimbrite eruption (see also Costa et al. 2012). Cornell et al. (1983) assumed that $50 \%$ of volcanic ash with a diameter between 44 and $63 \mu \mathrm{m}(4<$ $\Phi<4.6), 75 \%$ of volcanic ash with a diameter between 31 and $44 \mu \mathrm{m}(4.6<\Phi<5)$ and $100 \%$ of volcanic ash with diameter less than $32 \mu \mathrm{m}(\Phi \geq 5)$ fall as aggregates of $200 \mu \mathrm{m}$ diameter and density of $200 \mathrm{~kg} / \mathrm{m}^{3}$ (i.e. with terminal settling velocity of about $0.2 \mathrm{~m} / \mathrm{s}$ ). It is worth noting that, because of the discretization in settling velocity classes, different authors (e.g. Cioni et al. 2003; Macedonio et al. 1988), implicitly accounted for aggregation processes. In fact, since for computational reasons, velocity classes were typically discretized in steps of $0.5 \mathrm{~m} / \mathrm{s}$ and the lowest velocity class, where all the fines were included, was $0.5 \mathrm{~m} / \mathrm{s}$, that implies the class of $0.5 \mathrm{~m} / \mathrm{s}$ was implicitly considered as the effective settling velocity class of the aggregates, a value similar to that used by Armienti et al. (1988) for the $1980 \mathrm{Mt}$. St. Helens eruption.

\section{Terminal settling velocity}

The evaluation of particle terminal settling velocity from the Total Grain Size Distribution (TGSD) is not trivial because of the irregular and variable shape of the real pyroclast particles (Armienti et al. 1988; Pfeiffer et al. 2005; Wilson and Huang 1979). Usually, it is obtained 
combining both theoretical models and experimental measurements (e.g. Arastoopour et al. 1982; Bagheri et al. 2015; Dellino et al. 2005; Ganser 1993; Wilson and Huang 1979). The terminal settling velocity depends on particle size, shape, and density and plays an important role on tephra dispersal (e.g. Pfeiffer et al. 2005). Normally, the densest and greatest particles fall near the volcanic vent, less dense and finest particles are instead dispersed farther from the volcanic vent. This natural trend is not valid in presence of significant volcanic ash aggregation, as discussed above.

Figure 4 shows, for different settling velocity models, the terminal settling velocity as a function of the particle size, assuming the densities reported in Table 2.

In our analysis we consider different settling velocity distributions (Fig. 5). The first settling velocity distribution (VSET-1990, Fig. 5a) has seven classes between 1 and $9 \mathrm{~m} / \mathrm{s}$. In this distribution, the particles with speed greater than $9 \mathrm{~m} / \mathrm{s}$ (about $6.25 \%$ ) are considered inside the last class. This settling velocity distribution (Macedonio et al. 1990) was adopted for the definition of the "Maximum Expected Event", on which the 2001 Vesuvius Emergency Plan was based (DPC 2001).The terminal settling velocity distributions shown in Fig. $5 \mathrm{~b}$ and c, were derived from the TGSD introduced by Cioni et al. (2003) and identified as "79 type" (here, VSET-79) and "1631 type" (here, VSET-1631). The last settling velocity distribution, shown in Fig. 5d (VSET-2008), was derived from the TGSD of sub-Plinian and Plinian eruptions at Vesuvius. This TGSD was firstly presented by Cioni et al. at the Final Workshop of the European Project "Exploris", held in Naples (Italy) on May 10-13 2006, and was adopted by Macedonio et al. (2008) for volcanic hazard analysis at Vesuvius. As shown

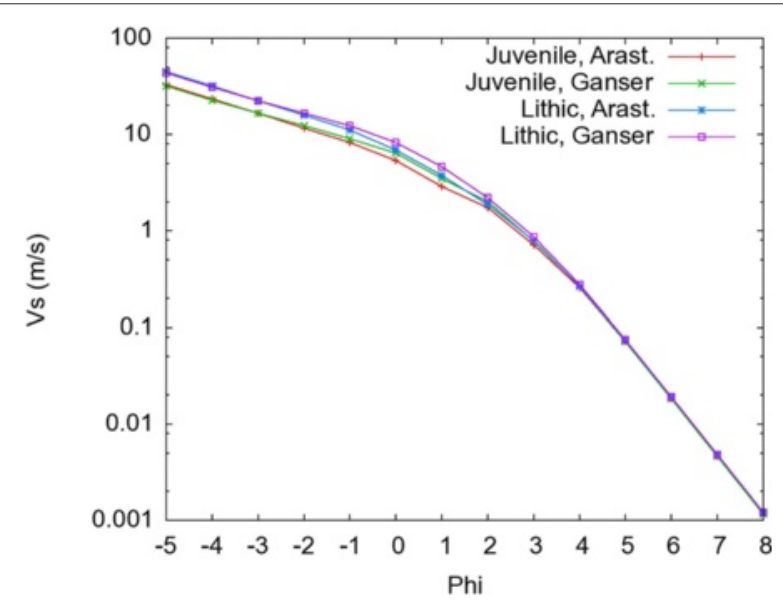

Fig. 4 Terminal settling velocity $(\mathrm{m} / \mathrm{s})$ of juvenile and lithic particles as a function of the particle size. The used models are Arastoopour et al. (1982) reported in the legend as "Arast." and Ganser (1993) reported in the legend as "Ganser" using a sphericity of 0.9
Table 2 Grain size and particle density distribution used to produce the settling velocity distribution "VSET-2008" reported in Fig. 5d. Particle densities are from Macedonio et al. (1990)

\begin{tabular}{lllllll}
\hline \multirow{2}{*}{$\Phi$} & Total & \multicolumn{2}{c}{ Juveniles } & & \multicolumn{2}{c}{ Lithics } \\
\cline { 7 - 7 } & $w t \%$ & Density & $w t \%$ & & Density & wt $\%$ \\
\hline-5 & 1 & 1400 & 80 & & 2600 & 20 \\
-4 & 4 & 1400 & 80 & & 2600 & 20 \\
-3 & 7 & 1400 & 80 & & 2600 & 20 \\
-2 & 6 & 1400 & 80 & & 2600 & 20 \\
-1 & 6 & 1400 & 80 & & 2600 & 20 \\
0 & 12 & 1700 & 80 & & 2600 & 20 \\
1 & 17 & 1700 & 80 & & 2600 & 20 \\
2 & 10 & 2300 & 80 & & 2600 & 20 \\
3 & 6 & 2300 & 80 & & 2600 & 20 \\
4 & 7 & 2500 & 80 & & 2600 & 20 \\
5 & 9 & 2500 & 80 & & 2600 & 20 \\
6 & 9 & 2500 & 80 & & 2600 & 20 \\
7 & 5 & 2500 & 80 & & 2600 & 20 \\
8 & 1 & 2500 & 80 & & 2600 & 20 \\
\hline
\end{tabular}

in Table 2, this TGSD includes an estimation, based on field data, of the mass fraction of fine particles up to $\Phi=8$. For this distribution ten velocity classes ranging between 0.5 and $18.5 \mathrm{~m} / \mathrm{s}$ with $2 \mathrm{~m} / \mathrm{s}$ steps were considered.

It is worth noting that, due to the variation of the air density and viscosity with the altitude, the particle settling velocity has different values at different heights and changes, therefore, during the particle fall. For this reason, in this work, the terminal velocity is evaluated at each height by adopting the same approach used by Pfeiffer et al. (2005), who considered an empirical settling velocity-altitude relationship for each particle size.

\section{Column height}

Column height is an important input parameter of tephra dispersal models. The height reached by the column increases with the mass eruption rate (e.g. Wilson and Walker 1987) and, for this reason, it is often used to estimate the mass eruption rate from column observations. Furthermore, particles leaving the eruption column at different heights are affected by different winds and can be transported in different directions. In this study, the column height is set to $18 \mathrm{~km}$, within the range $15-20 \mathrm{~km}$ proposed by Cioni et al. (2008) for sub-Plinian (type I) eruptions, and this value has been varied of about $20 \%$, i.e. from 12 to $22 \mathrm{~km}$. The vertical distribution of the particle mass in the column is parameterized according to Suzuki (1983), assuming a shape coefficient of 4. This parameterization was subsequently adopted, among others, by Armienti et al. (1988); Macedonio et al. (2005) and generalized by Pfeiffer et al. (2005). 

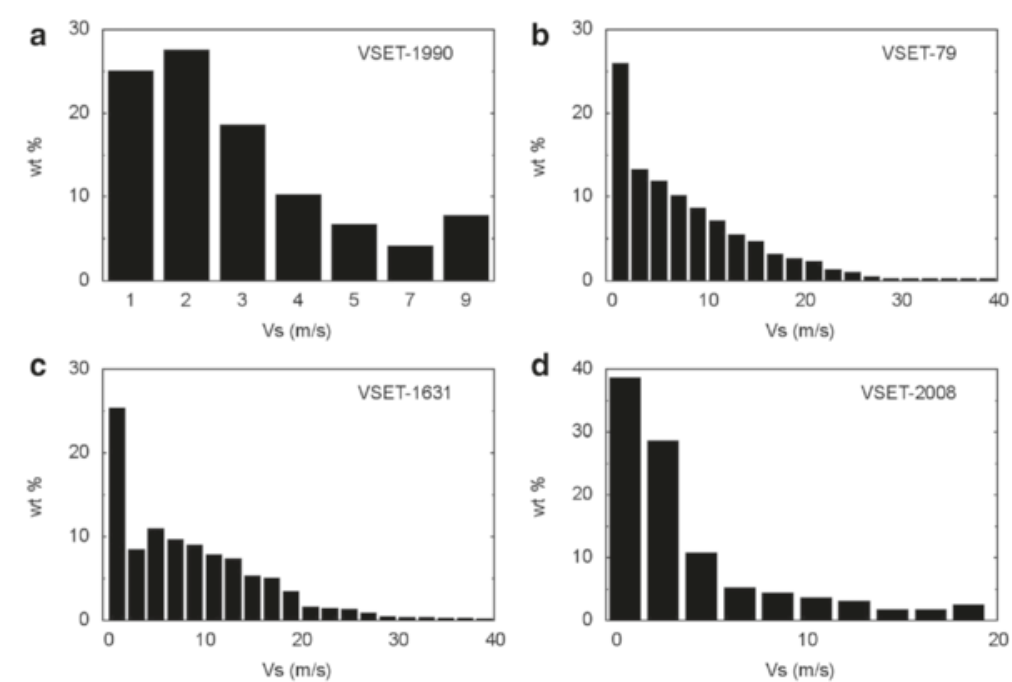

Fig. 5 Settling velocity distributions. a VSET-1990 used by Barberi et al. (1990) and Macedonio et al. (1990); b VSET-79, used by Cioni et al. (2003); c VSET-1631 used by Cioni et al. (2003); d VSET-2008, used by Macedonio et al. (2008). See text for explanation

\section{Horizontal diffusion coefficient}

The effective horizontal atmospheric diffusion coefficient is an empirical parameter adopted in plume models, that describes the effective spreading due to atmospheric turbulence and gravitational spreading at the Neutral Buoyancy Level (Costa et al. 2013). It is usually obtained by best-fit procedure (e.g. Bonadonna et al. 2002; Bonasia et al. 2010; Macedonio et al. 1988) and typically ranges between $10^{2}$ and $10^{4} \mathrm{~m}^{2} / \mathrm{s}$. Studies on Vesuvius eruptions have shown that the horizontal diffusion coefficient, for sub-Plinian and Plinian eruptions, for the target area, ranges between 1000 and $10,000 \mathrm{~m}^{2} / \mathrm{s}$ (Bonasia et al. 2010; Macedonio et al. 1988).

\section{Results}

In this section we analyze the sensitivity of hazard maps to a change in the input parameters. We take as reference parameter the area with probability greater than $5 \%$ of a loading equal to $300 \mathrm{~kg} / \mathrm{m}^{2}$, although we explore also the effects on other thresholds. The choice of the thresholds is consistent with the values typically adopted by the Italian
Department of Civil Protection for zoning the fallout hazard in the Emergency Plan (DPC 2001; 2015; Regione Campania 2015). The main input parameters are reported in Table 3. In the following subsections, we discuss how the extension and shape of the hazard zone changes by varying the meteorological wind field dataset, the total mass of the eruption, the particles settling velocity distribution, the column height, and the effective diffusion coefficient.

\section{Effect of the meteorological dataset}

The meteorological conditions play a major role in defining the zone subject to tephra fallout. As mentioned before, we tested both data from radio-soundings recorded in different locations in Italy and data from model reanalysis performed by the NOAA and the ECMWF meteo centers. As shown in Fig. 6, the hazard maps do not show significant differences associated to the use of different meteorological data. In particular, using the radio-soundings BRIN, LIBR, and LIRE we obtain a hazard area of 933,955 and $991 \mathrm{~km}^{2}$, respectively,

Table 3 Computational and input parameters

\begin{tabular}{lll}
\hline Description & Reference & Variation range \\
\hline Total mass & $5 \times 10^{11} \mathrm{~kg}$ & $10^{11}-10^{12} \mathrm{~kg}$ \\
Column height & $18 \mathrm{~km}$ & $12-22 \mathrm{~km}$ \\
Horizontal diffusion coefficient & $5000 \mathrm{~m}^{2} / \mathrm{s}$ & $1000-10000 \mathrm{~m}^{2} / \mathrm{s}$ \\
Column shape (Suzuki coefficient) & 4 & unchanged \\
Meteorological data & ERA Interim & see Table 1 \\
Settling velocity distribution & VSET-2008 & VSET-1990,-79, -1631,-2008 \\
Grid spacing & $400 \times 400 \mathrm{~m}$ & unchanged \\
\hline
\end{tabular}



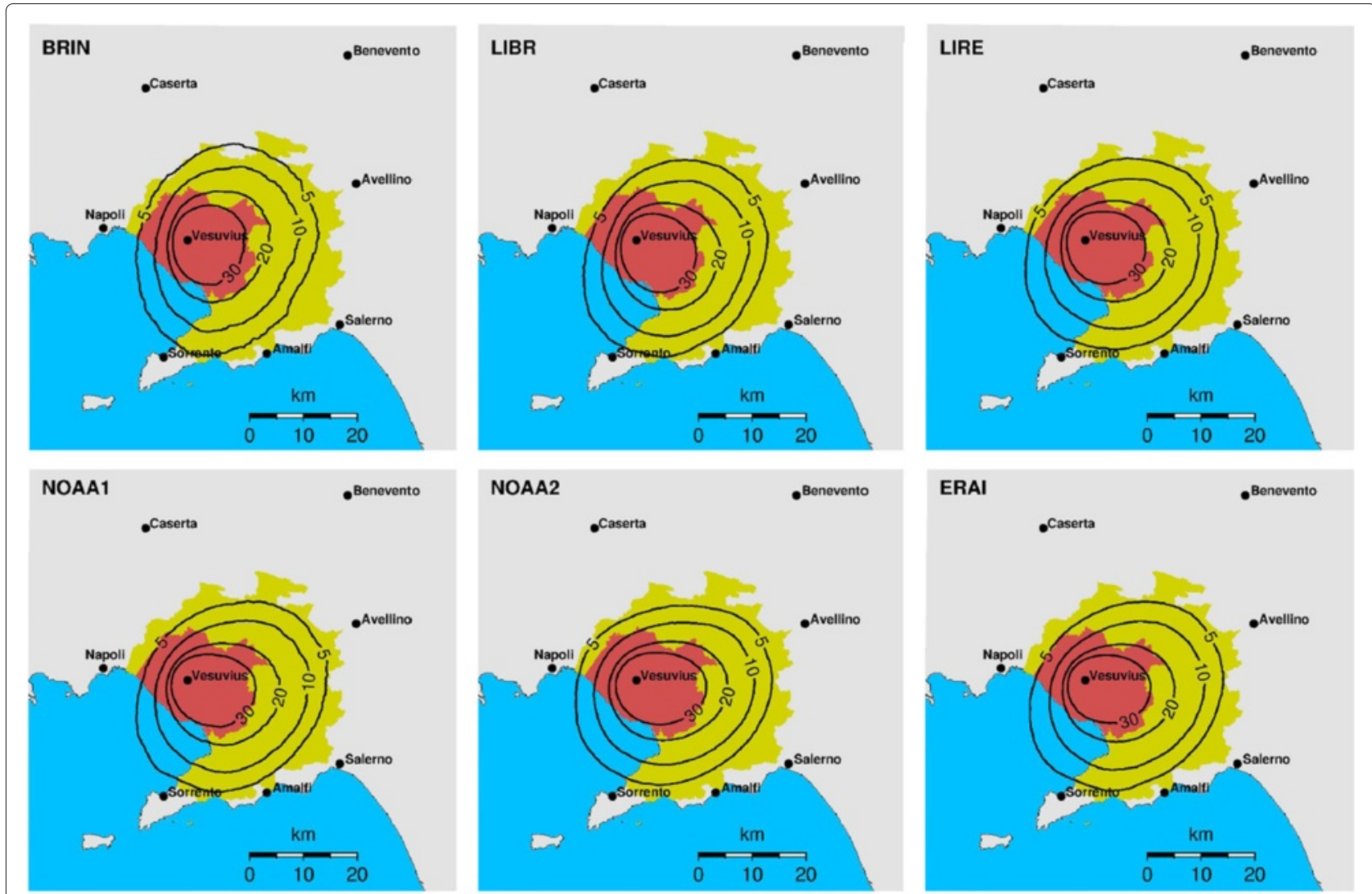

Fig. 6 Effect of the meteorological dataset on the hazard maps. Contours represent the probability of loading greater that $300 \mathrm{~kg} / \mathrm{m}^{2}$. Upper plots (BRIN, LIBR and LIRE) refer to radio-soundings, whereas the lower plots (NOAA1, NOAA2 and ERAI) refer to data Reanalysis. The extent of the area within the $5 \%$ probability contour is $993,955,991,966,962$ and $972 \mathrm{~km}^{2}$, respectively, for the BRIN, LIBR, LIRE, NOAA1, NOAA2 and ERAI dataset (see also Fig. 7). In the background are reported the "Red Zone" (hazard from pyroclastic flows and lahars) and the "Yellow Zone" (hazard from ash fallout) of the actual Emergency Plan of Vesuvius (DPC 2015; Regione Campania 2015)

whereas the reanalysis datasets NOAA1, NOAA2 and ERAI give a hazard area of 966, 962 and $972 \mathrm{~km}^{2}$, respectively. The difference in the area extension, for loading of $300 \mathrm{~kg} / \mathrm{m}^{2}$, is therefore lower than $2 \%$ and shows that the use of different meteorological datasets has a minor effect on the hazard distribution. Moreover, we compared also the hazard area for tephra loading equal to 500 and $1000 \mathrm{~kg} / \mathrm{m}^{2}$. Results are shown in the histogram of Fig. 7. Differences in the hazard area, again represented as the area with probability greater than $5 \%$, obtained by using different meteorological datasets, are 2 , 2.4 and $6.6 \%$, respectively for ash loading of 300,500 and $1000 \mathrm{~kg} / \mathrm{m}^{2}$.

Figure 8 shows the seasonal effect on the extension of the hazard zone. The four seasons Spring, Summer, Autumn, and Winter are each represented by a subset of three months extracted from the total dataset (Spring: from March 1 to June 30, Summer: from July 1 to September 30, Autumn: from October 1 to December 31, Winter: from January 1 to February 28/29). For

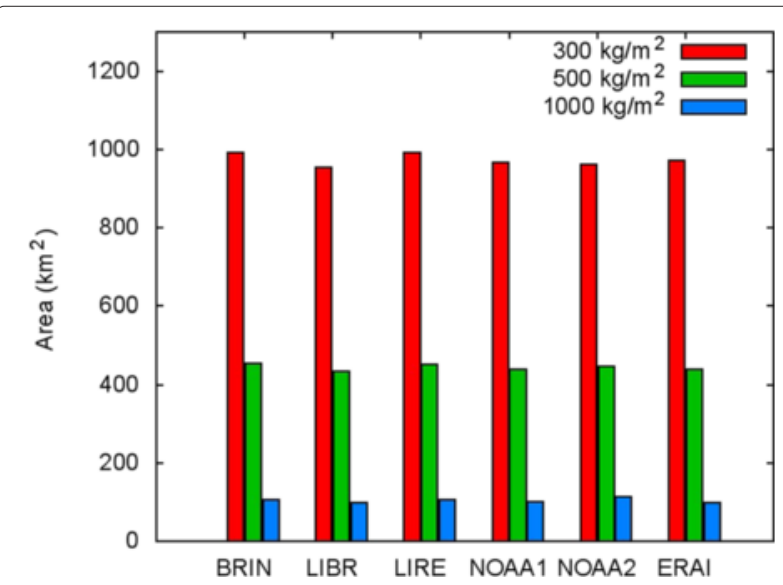

Fig. 7 Area with probability greater than $5 \%$ of ash loading equal to a given threshold, for different meteorological datasets. Datasets BRIN, LIBR and LIRE refer to radio-soundings, whereas datasets NOAA1, NOAA2 and ERAI refer to data reanalysis (see text). The histogram shows that the use of different meteorological dataset does not affect significantly the extension of the hazard zone 

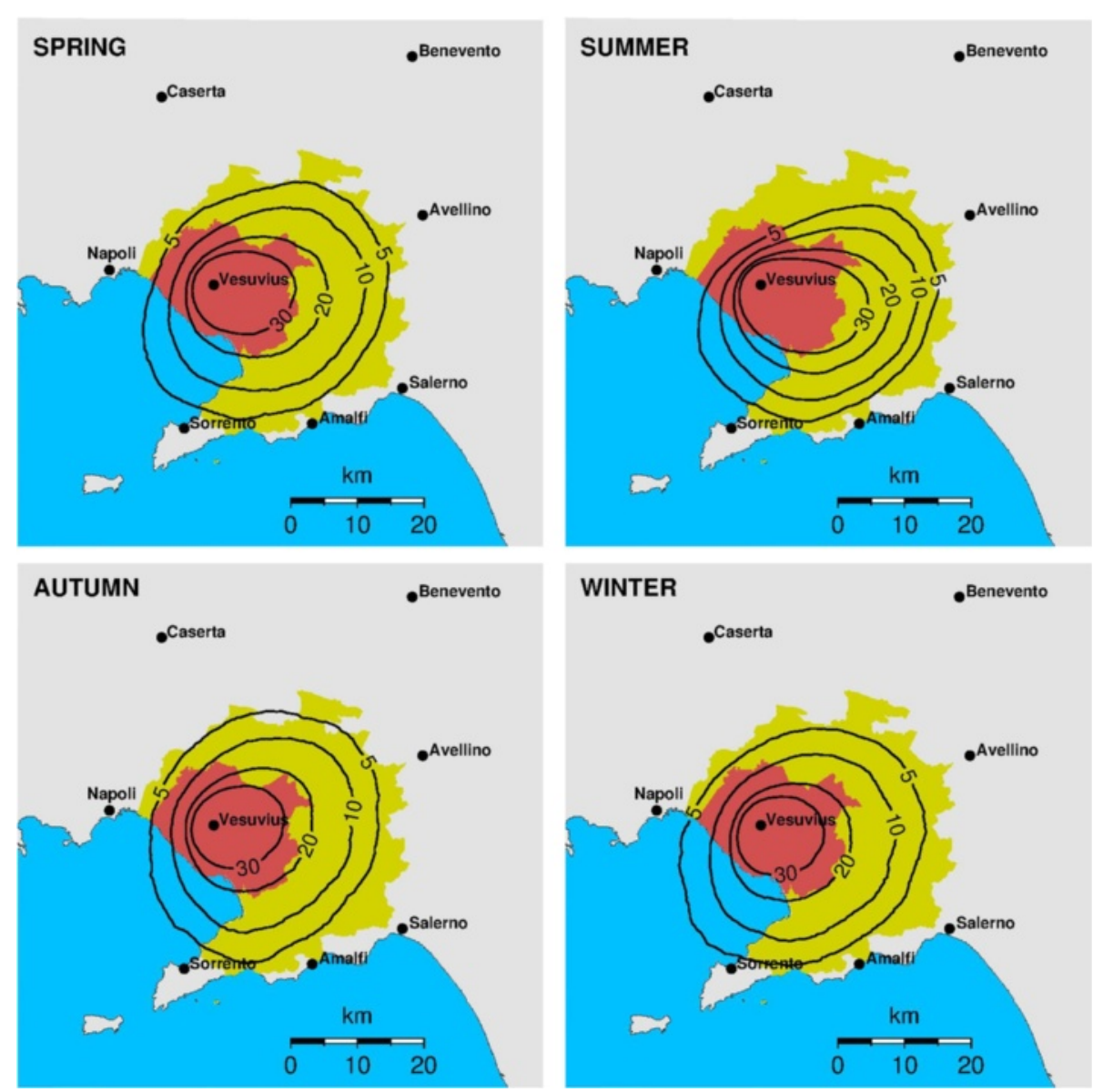

Fig. 8 Effect of the season on the hazard maps. Contours represent the probability of loading greater that $300 \mathrm{~kg} / \mathrm{m}^{2}$, for the reference scenario. The ECMWF ERA Interim (ERAI) dataset was used. The areas enclosed by the $5 \%$ probability contour is $1004,861,965$ and $1008 \mathrm{~km}^{2}$, for Spring, Summer, Autumn and Winter, respectively. In the background are reported the "Red Zone" (hazard from pyroclastic flows and lahars) and the "Yellow Zone" (hazard from ash fallout) of the actual Emergency Plan of Vesuvius (DPC 2015; Regione Campania 2015)
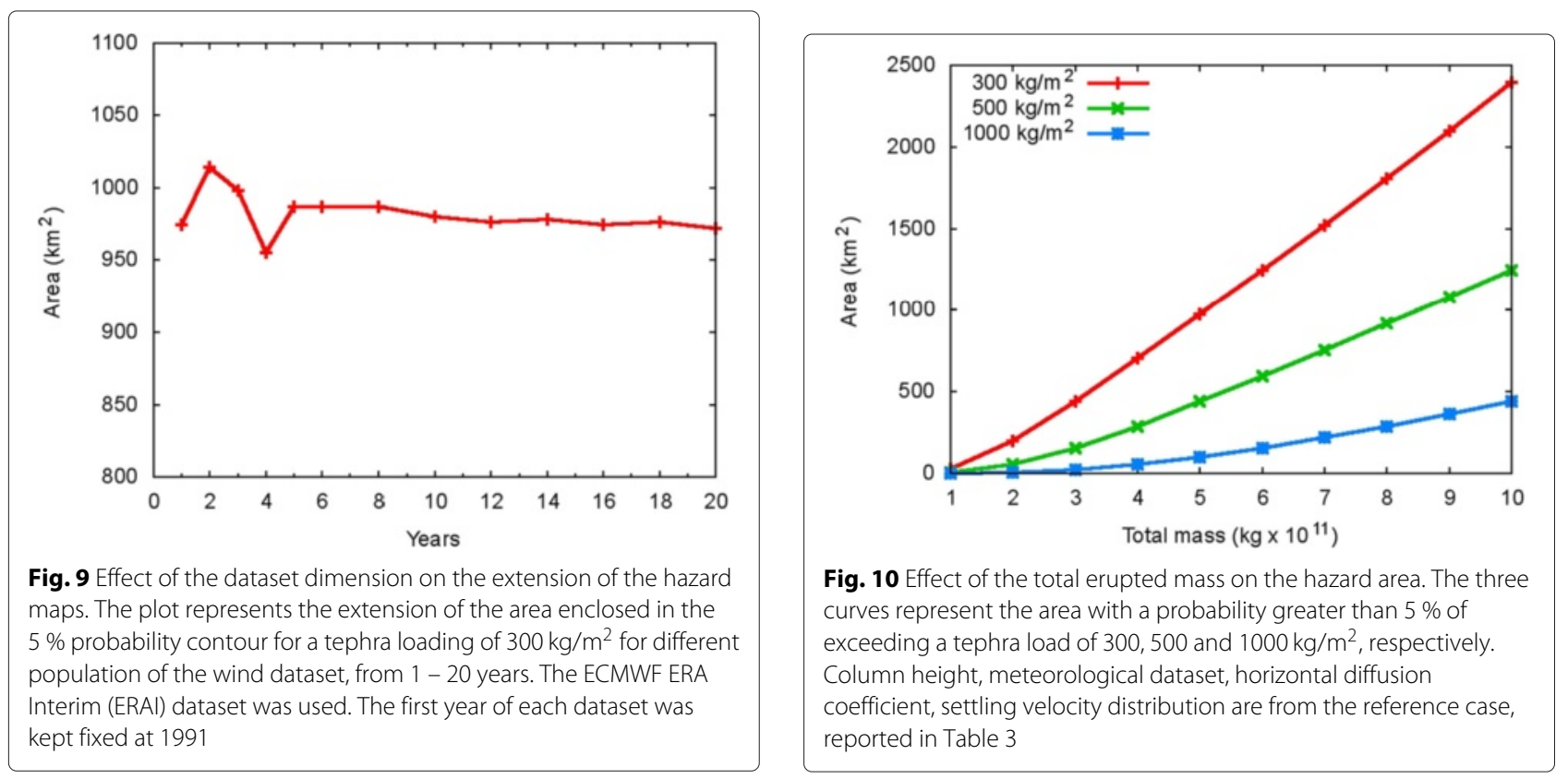

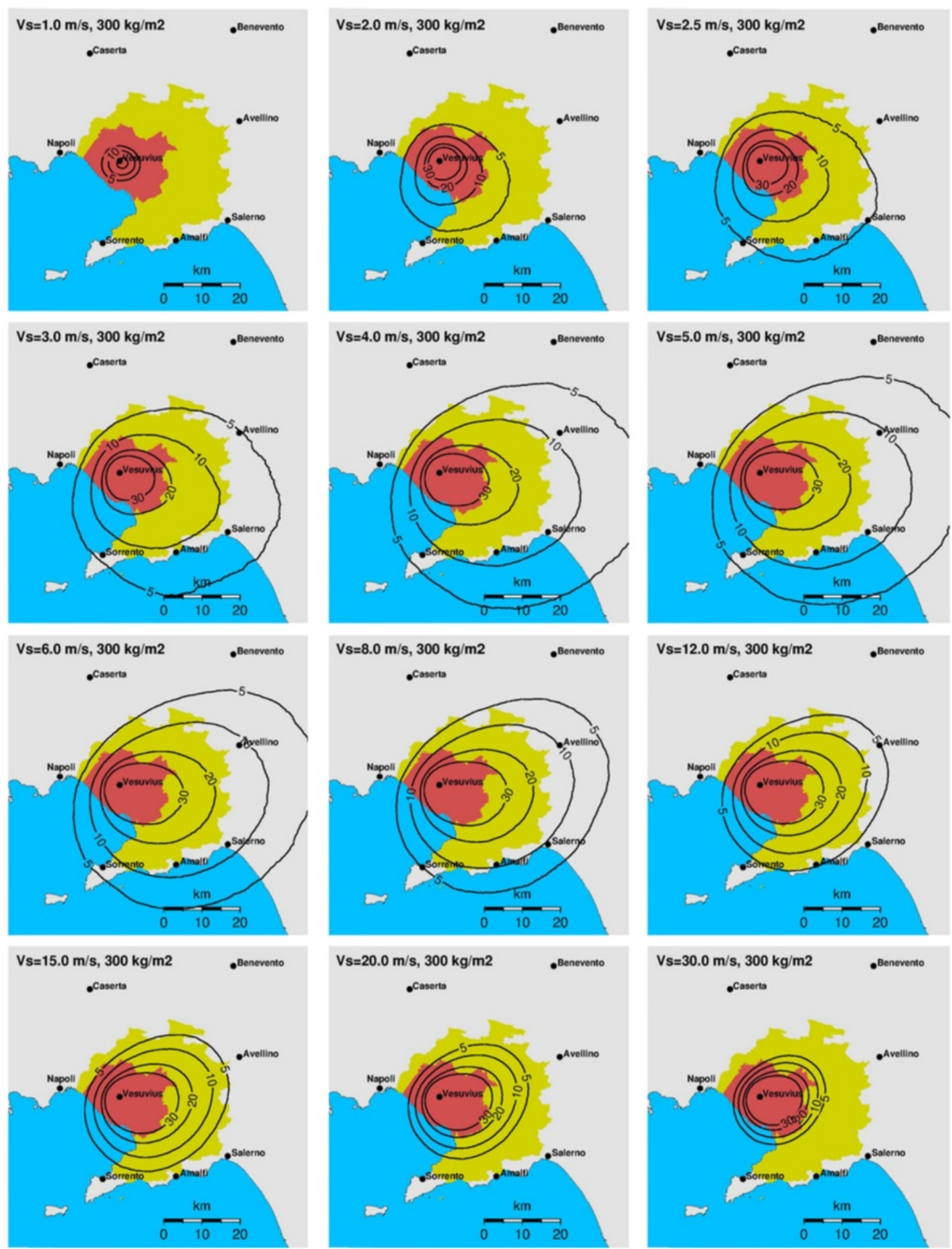

Fig. 11 Effect of the terminal settling velocity on the hazard maps $\left(300 \mathrm{~kg} / \mathrm{m}^{2}\right)$. Contour lines represent different probabilities of loading greater than the threshold $300 \mathrm{~kg} / \mathrm{m}^{2}$. Total mass is $5 \times 10^{11} \mathrm{~km}$, column height of $18 \mathrm{~km}$ and diffusion coefficient of $5000 \mathrm{~m}^{2} / \mathrm{s}$. Wind dataset is from the ERA-Interim of the ECMWF model between 1991 and 2010. Each frame represents the probability distribution of a simulation with all particles of just one terminal settling velocity. The aim of this plot is to show how the different settling velocity class contribute to the extension of the hazard maps. Maximum extension is obtained for particles with settling velocity of $5 \mathrm{~m} / \mathrm{s}\left(2,983 \mathrm{~km}{ }^{2}\right.$ ). In the background are reported the "Red Zone" (hazard from pyroclastic flows and lahars) and the "Yellow Zone" (hazard from ash fallout) of the actual Emergency Plan of Vesuvius (DPC 2015; Regione Campania 2015) 

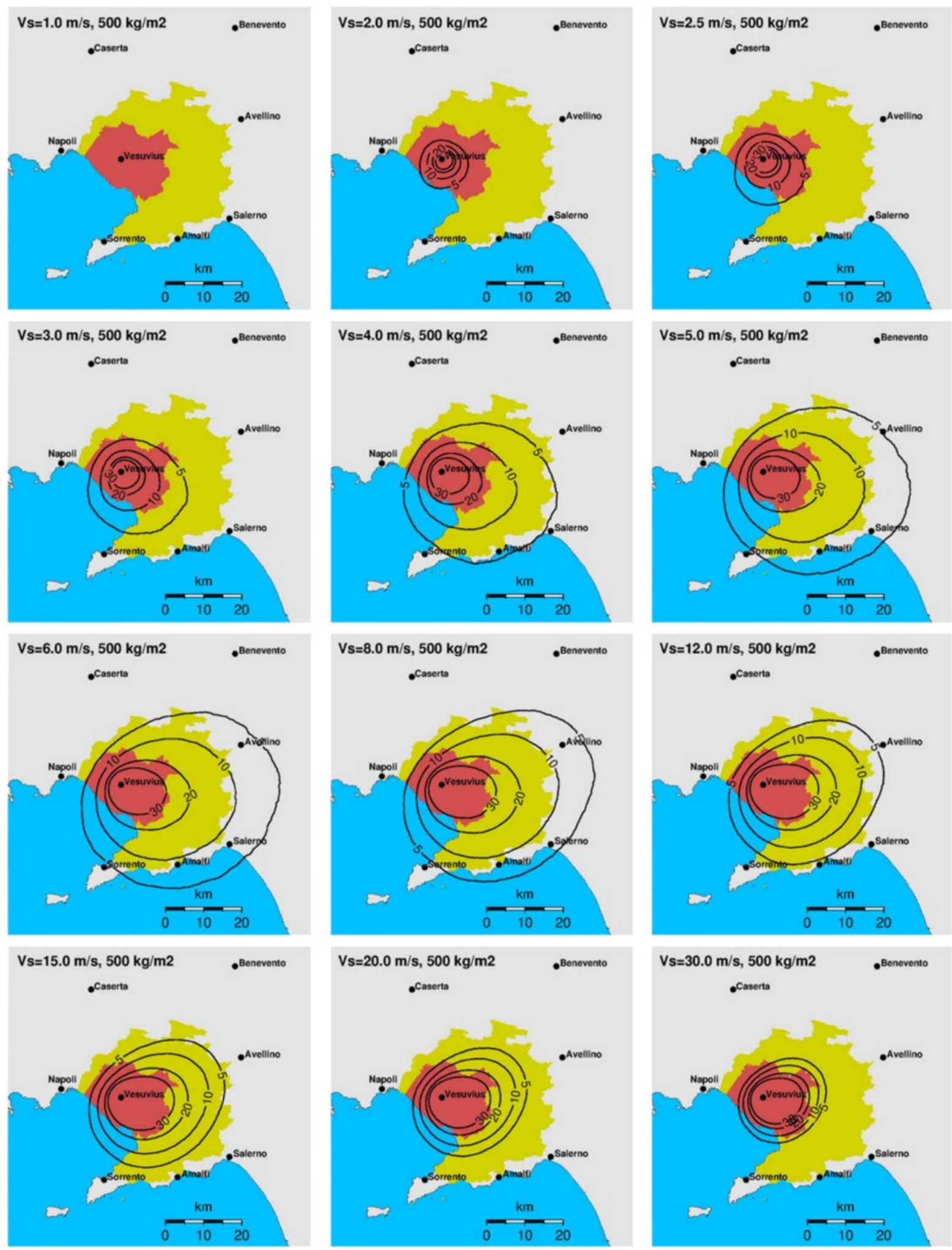

Fig. 12 Effect of the terminal settling velocity on the hazard maps $\left(500 \mathrm{~kg} / \mathrm{m}^{2}\right)$. Contour lines represent different probabilities of loading greater than the threshold $500 \mathrm{~kg} / \mathrm{m}^{2}$. Input parameters as for Fig. 11. Maximum extension is obtained for particles with settling velocity of $6 \mathrm{~m} / \mathrm{s}$ $\left(1,831 \mathrm{~km}^{2}\right)$. In the background are reported the "Red Zone" (hazard from pyroclastic flows and lahars) and the "Yellow Zone" (hazard from ash fallout) of the actual Emergency Plan of Vesuvius (DPC 2015; Regione Campania 2015) 

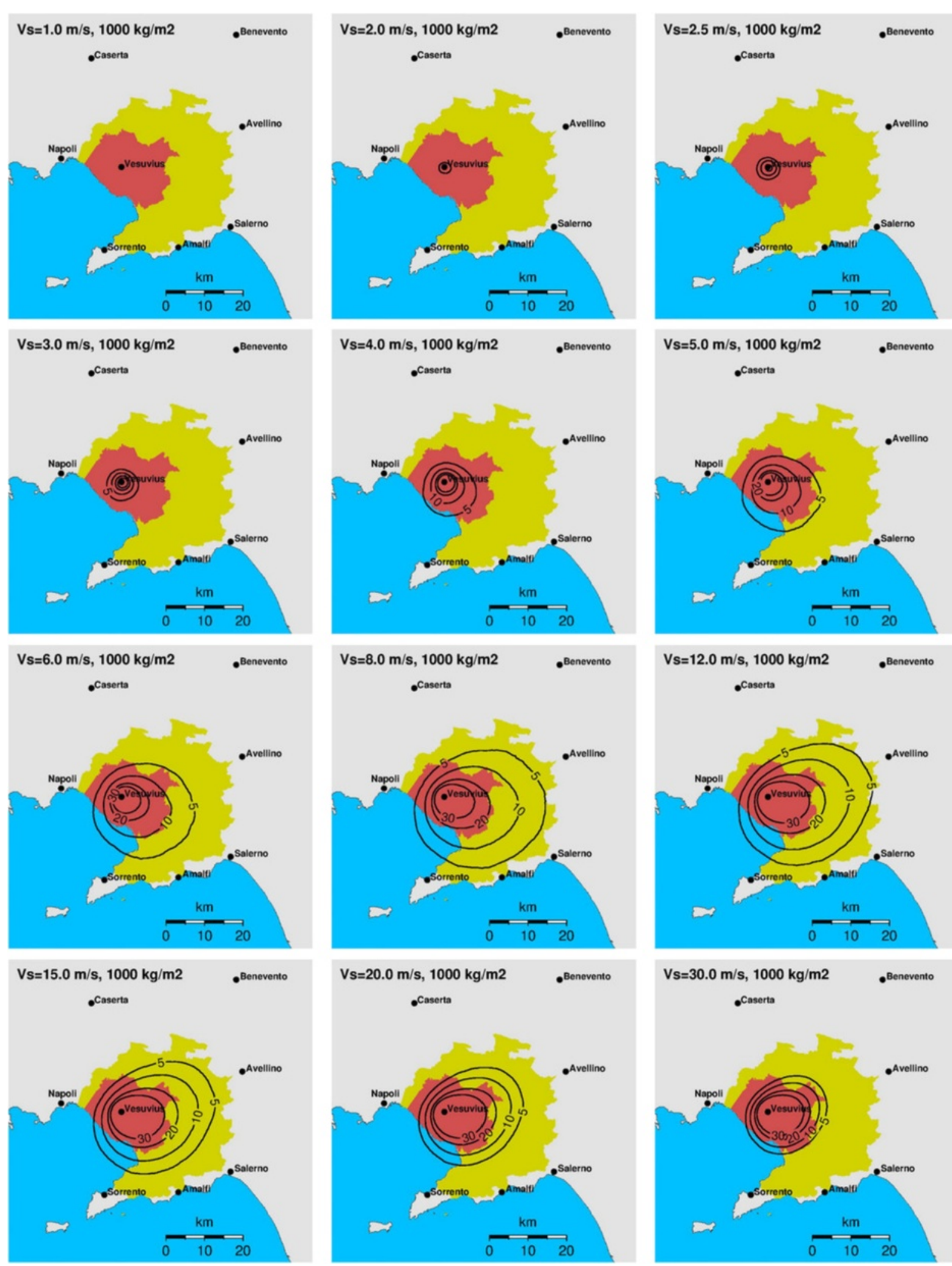

Fig. 13 Effect of the terminal settling velocity on the hazard maps $\left(1000 \mathrm{~kg} / \mathrm{m}^{2}\right)$. Contour lines represent different probabilities of loading greater than the threshold $1000 \mathrm{~kg} / \mathrm{m}^{2}$. Input parameters as for Fig. 11. Maximum extension is obtained for particles with settling velocity of $10 \mathrm{~m} / \mathrm{s}$ $\left(886 \mathrm{~km}^{2}\right)$. In the background are reported the "Red Zone" (hazard from pyroclastic flows and lahars) and the "Yellow Zone" (hazard from ash fallout) of the actual Emergency Plan of Vesuvius (DPC 2015; Regione Campania 2015) 
sake of simplicity, only hazard maps obtained from the ECMWF ERA-Interim dataset, in the period 1991-2010, are shown. The areas enclosed in the $5 \%$ probability contour for the tephra loading of $300 \mathrm{~kg} / \mathrm{m}^{2}$ are 1004, 861, 965 and $1008 \mathrm{~km}^{2}$ for Spring, Summer, Autumn and Winter, respectively, suggesting that in Winter, and to some extent Spring, probabilities for exceeding the given ash thickness thresholds will be larger, and extend slightly towards the east in Summer.

Finally, an analysis on the temporal length of the wind dataset was also performed. Figure 9 shows the extension of the hazard area (area with probability greater than $5 \%$ of tephra loading equal to $300 \mathrm{~kg} / \mathrm{m}^{2}$ ), for datasets with different temporal extension. The test was performed for the ECMWF ERA-Interim dataset only. This figure shows that the extension of the hazard zone is almost stable when datasets temporally extending for more than about 5 years are used.

\section{Effect of the total mass}

The erupted mass is the primary parameter affecting the extension of the hazard zone. As we mentioned above, keeping fixed all other parameters, a variation in the total mass produced a linear variation in the deposit loading. In general, the relationship between the total mass and the extension of the area having a given probability of being covered by a deposit of a given threshold is not linear, because of the non-linearity of the operation of thresholding (thresholding produces a null hazard area when the erupted mass is insufficient for reaching the given loading).

However, within the investigated range of erupted mass, a quasi-linear relationship between the extension of the hazard zone and the total mass was obtained, for different loading thresholds, as shown in Fig. 10.

\section{Effect of the terminal settling velocity}

The variation of the terminal settling velocity distribution, and therefore of the TGSD, affects the probability maps in a way that is not straightforward and obvious. Such understanding is important to better explain the discrepancies that may arise when different TGSDs (and consequently terminal settling velocity distributions) are used in tephra dispersal models for hazard assessment. Particles having smaller settling velocities are dispersed on a greater area with a decrease of the deposit loading. In order to perform this analysis, we assume a synthetic eruption mixture composed of particles belonging just to one terminal settling velocity class. The considered terminal settling velocity ranges between 0.5 and $30 \mathrm{~m} / \mathrm{s}$. As reference, the total mass is set $5 \times 10^{11} \mathrm{~kg}$, the column height $18 \mathrm{~km}$, and the horizontal diffusion coefficient $5000 \mathrm{~m}^{2} / \mathrm{s}$. The meteorological dataset ERA-Interim of ECMWF between 1991 and 2010, with a time steps of $6 \mathrm{~h}$ and 29,220 wind profiles, was used. Results of the tephra dispersal simulations are reported in Fig. 11. It is worth noting that there is a class of terminal settling velocity that produces a maximum area for a given deposit load $(\approx 5 \mathrm{~m} / \mathrm{s}$, for a loading of $300 \mathrm{~kg} / \mathrm{m}^{2}$ ). The simulations obviously represent only a theoretical situation because all real eruptions eject a large number of particle sizes spanning several orders of magnitude. However, these results demonstrate clearly that there are some particles sizes that give a greater contribution on tephra loading in the target area. As mentioned above, this effect is due to the fact that the particles having a small terminal settling velocity disperse on a greater area and, consequently, the mass loading will not exceed the threshold of $300 \mathrm{~kg} / \mathrm{m}^{2}$, except for a small amount of particles that are released from the lower part of the column height whose loading overcomes $300 \mathrm{~kg} / \mathrm{m}^{2}$ near the volcanic vent only. Figures 12 and 13 show the probability maps for loading thresholds of 500 and $1000 \mathrm{~kg} / \mathrm{m}^{2}$, respectively, for each settling velocity class. As it can be noted, that the velocity class that produces the maximum hazard area varies with the hosen loading threshold. Figure 14 reports the effects of the terminal settling velocity of volcanic particles on the area with deposit load of $300 \mathrm{~kg} / \mathrm{m}^{2}$ (probability map of $5 \%$ ) for different eruption and weather conditions.

To study the effect of the whole settling velocity distribution, we performed simulations using the four different distributions defined above: VSET-79, VSET-1900, VSET1631, and VSET-2008. Results, reported in Fig. 15, show

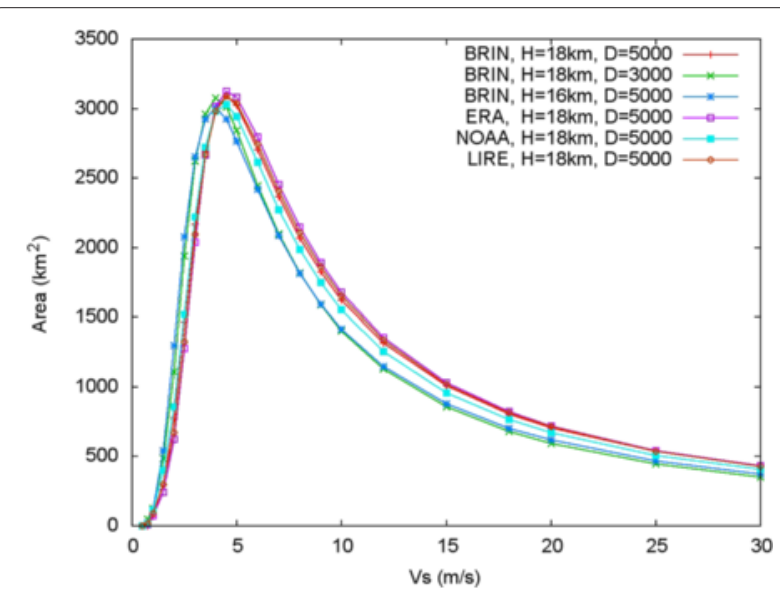

Fig. 14 Effect of the terminal settling velocity of the ash particles on the extension of the hazard zone. The hazard zone is represented by the area enclosed by the $5 \%$ probability contour of a deposit loading equal to $300 \mathrm{~kg} / \mathrm{m}^{2}$. Eruption column ranges between 16 and $18 \mathrm{~km}$, the diffusion coefficient between 3000 and $5000 \mathrm{~m}^{2} / \mathrm{s}$. We use radio-sounding between 1962-1976 (Aeronautica Militare) recorded at Brindisi (BRIN), radio-sounding between 1962-1976 recorded at Pratica di Mare station between 1995-2013 (LIRE), 6-h NOAA-CIRES Reanalysis-2 model between 1991-2010 (NOAA) and of ECMWF ERA-Interim Full Resolution model between 1991-2010 (ERA) 

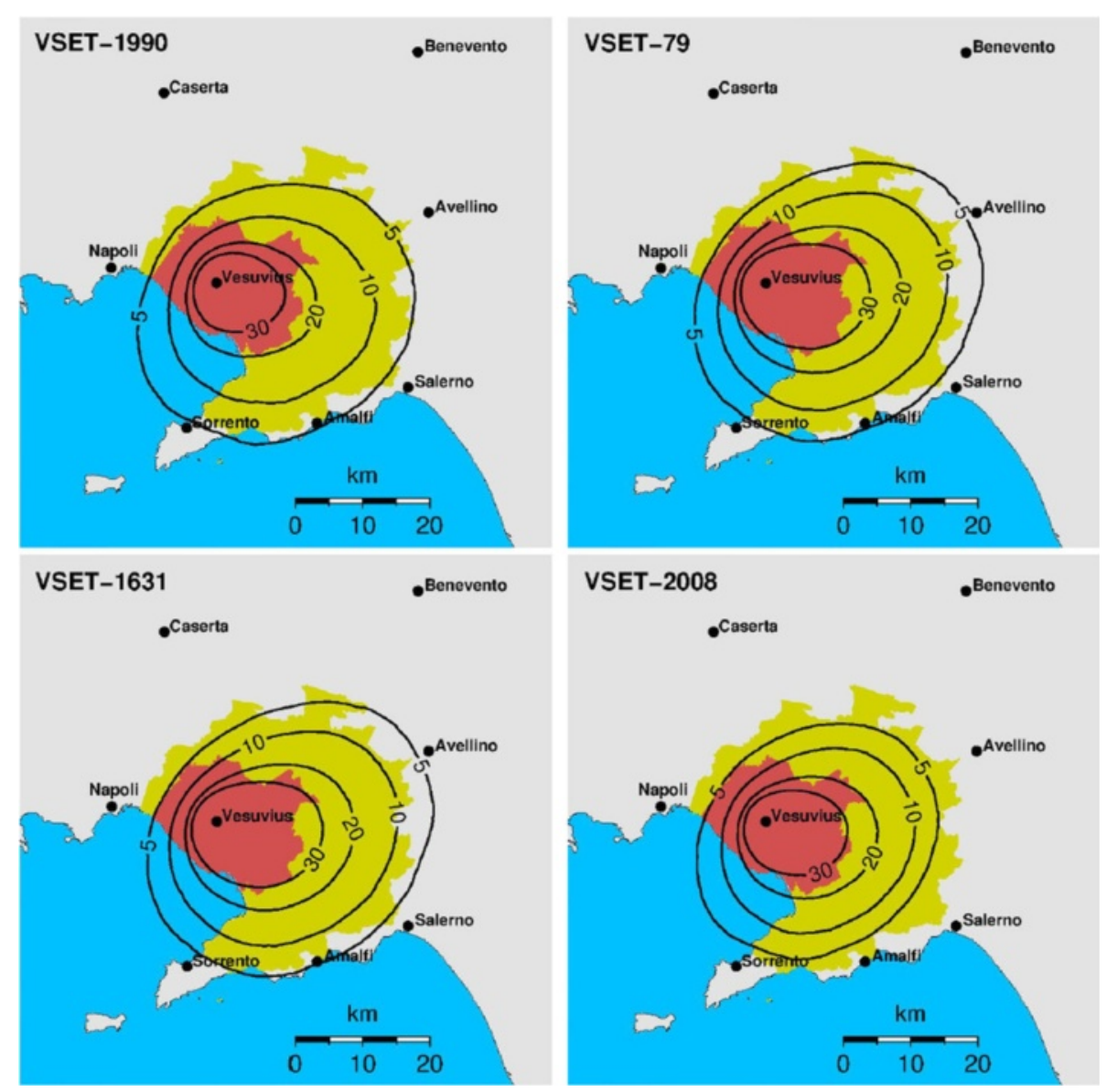

Fig. 15 Effect of the settling velocity distribution of the pyroclastic particles on the probability maps for a deposit load equal to $300 \mathrm{~kg} / \mathrm{m}^{2}$. The area enclosed within the $5 \%$ probability contour is 1232, 1356, 1319 and $972 \mathrm{~km}^{2}$, respectively, for the distribution VSET-1990, VSET-79, VSET-1631 and VSET-2008. In the background are reported the "Red Zone" (hazard from pyroclastic flows and lahars) and the "Yellow Zone" (hazard from ash fallout) of the actual Emergency Plan of Vesuvius (DPC 2015; Regione Campania 2015)

that the settling velocity distribution VSET-2008 produces a smaller hazard area; this is caused by the greater fraction of fine particles (particles with settling velocity smaller that $5 \mathrm{~m} / \mathrm{s}$ ) with respect to the other particle settling velocity distributions considered.

\section{Effect of the column height}

The column height has an important effect on the probability maps. For example, keeping fixed the terminal settling velocity equal to VSET-2008 (Fig. 5d) and the diffusion coefficient equal to $5000 \mathrm{~m}^{2} / \mathrm{s}$, variations of $10 \mathrm{~km}$ in the column height (from $12 \mathrm{~km}$ up to $22 \mathrm{~km}$ ) produce differences of 23,35 and $49 \%$ in the area enclosed by the $5 \%$ probability contour, for loading thresholds of 200,300 and $400 \mathrm{~kg} / \mathrm{m}^{2}$, respectively. Typically, keeping constant all the other source parameters, the higher the columns, the smaller the hazard area defined by a given loading threshold, as a consequence of the larger tephra dispersal. In the investigated range of column height, the hazard area decreases almost linearly with the increase of the column height. Figure 16 shows the probability map for ash loading exceeding $300 \mathrm{~kg} / \mathrm{m}^{2}$. For this simulation, we used the VSET-2008 settling velocity distribution and meteorological data from the ERA-Interim Full Resolution of ECMWF model between 1991-2010. In this case, the area enclosed by the $5 \%$ line ranges between 840 and $1175 \mathrm{~km}^{2}$ for column height of 22 and $12 \mathrm{~km}$, respectively.

\section{Effect of the horizontal diffusion coefficient}

Results from the parametric study shows that the horizontal diffusion coefficient is also critical in defining the hazard area. Figure 17 shows the area with probability greater than $5 \%$ of tephra loading greater equal to $300 \mathrm{~kg} / \mathrm{m}^{2}$ for different values of the horizontal diffusion coefficient. The hazard area decreases with the increase in the diffusion coefficient. This is again due to the spreading of tephra over a larger area and the consequent decrease of the deposit loading. However, for Plinian and subPlinian eruptions at Vesuvius, for the target area, this empirical parameter (Costa et al. 2013) typically varies 


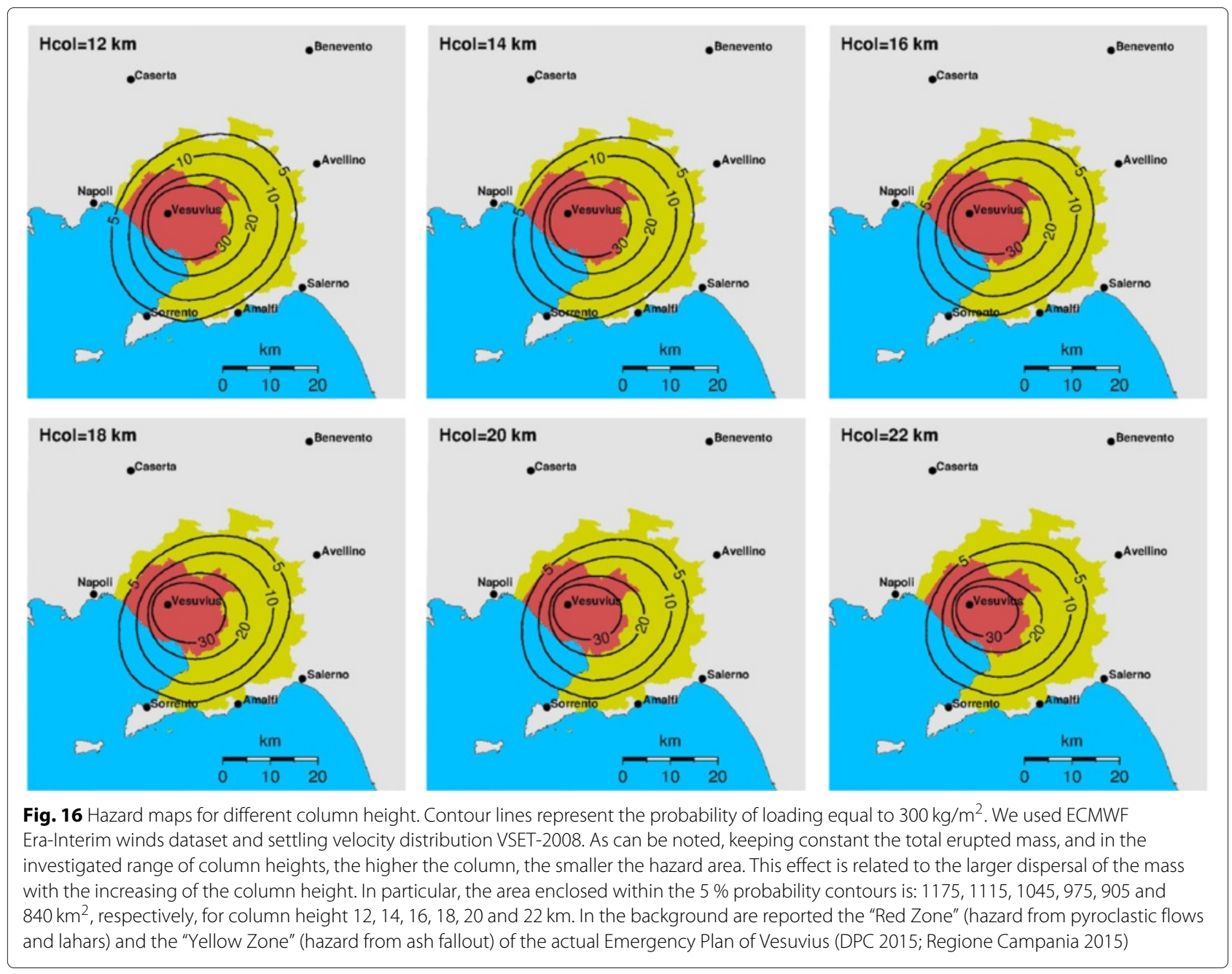

between 3000 and $5000 \mathrm{~m}^{2} / \mathrm{s}$ (e.g. Macedonio et al. 1988, Macedonio et al. 2008), resulting in a variation of about 6 $\%$ of the hazard area.

\section{Concluding remarks}

This work presents the results of a sensitivity analysis on tephra fall probability maps, based on a reference scenario, with the aim to evaluate the variability due to the use of different meteorological datasets and different eruption source parameters. The considered reference event is a sub-Plinian eruption of Vesuvius with a total mass of $5 \times 10^{11} \mathrm{~kg}$ and a column height of $18 \mathrm{~km}$. For comparison purposes, this study refers to the area with probability greater than $5 \%$ of tephra loading equal to $300 \mathrm{~kg} / \mathrm{m}^{2}$, here referred as "hazard zone", although also loading of 500 and $1000 \mathrm{~kg} / \mathrm{m}^{2}$ were investigated. These tephra loads are comparable with the collapse thresholds of roofs from low to medium-high resistance (Spence et al. 2005; Zuccaro et al. 2008).

From the simulation outcomes, we found that the total erupted mass has a first order effect on the extension of the hazard zone. The particles settling velocity also plays a crucial role, whereas the use of different meteorological datasets, and column height within the considered range do not affect significantly the hazard extension. Simulations show that there are some particles sizes that give a greater contribution on tephra loading in the target area. This effect is due to the fact that the particles having a different terminal settling velocity disperse on a different area. Since the particle settling velocity distribution, or the associated TGSD, is not easy to estimate, the probability maps are affected by large uncertainties. In fact, as mentioned above, the TGSD can be assessed by field analysis using statistical approaches (e.g. Bonadonna and Costa 2013; Bonadonna and Houghton 2005) or by inverse modeling (Bonasia et al. 2010; Mannen 2006) and the quality of this estimation strongly depends on the quantity and quality of the data (e.g. Barsotti et al. 2010; Bonadonna et al. 2015). The lacking of proximal points, often inaccessible, and distal points, often eroded or unavailable (e.g. in the sea), may in fact seriously affect the assessment of the total grain-size distribution (Bonadonna and Houghton 2005; 


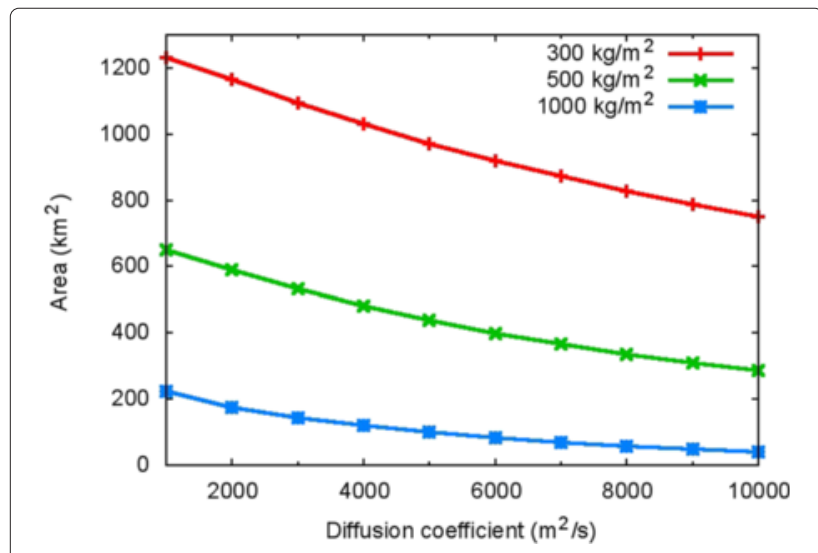

Fig. 17 Area with probability greater than $5 \%$ of tephra loading equal to 300,500 and $1000 \mathrm{~kg} / \mathrm{m}^{2}$, for different values of the horizontal diffusion coefficient. Figure shows the variation of the hazard area for a diffusion coefficient ranging between 1000 and $10,000 \mathrm{~m}^{2} / \mathrm{s}$, for three different loading thresholds. Typically, for Plinian and sub-Plinian eruptions at Vesuvius the diffusion coefficient varies between 3000 and $5000 \mathrm{~m}^{2} / \mathrm{s}$, resulting in a variation of less than $6 \%$ of the hazard area

Bonadonna et al. 2015; Bonasia et al. 2010). Our analysis shows that at the investigate latitude $\left(\approx 42^{\circ} \mathrm{N}\right)$ the wind field shows important seasonal variations at altitudes greater than about $15 \mathrm{~km}$. For the considered reference scenario (column height $18 \mathrm{~km}$ ), this leads to a variation of about $15 \%$ in the extension of the hazard zone between Summer and Winter.

As a final remark, concerning the tephra loading, we need to consider the potential effect of rain. In fact, tephra fall deposits are porous and incoherent. In case of rain, tephra deposits are able to absorb water within the pores up to a maximum level, beyond which the deposit becomes unstable and mobilized. Typically, the limit of instability is reached for volume fractions of water in the range of 23-47 \% (Pierson 1986). Before mobilization, the load is given by the sum of the deposit load plus the load of the rain stored by the deposit (Macedonio and Costa 2012). An estimation of the contribution of the rain to the deposit load, applied to the pyroclastic deposits in the Neapolitan area was considered by Macedonio and Costa (2012) that account for the statistics of the rains in the Neapolitan area (Fiorillo and Wilson 2004; Macedonio and Costa 2012). In order to estimate the maximum tephra load, Macedonio and Costa (2012) assumed that the deposit absorbs all the water up to the limit of remobilization or up to the maximum available water. In the latter case, they considered the maximum events of rain in the Neapolitan area during the last century (about $200 \mathrm{~mm}$ of rain per month, and the extreme event of $500 \mathrm{~mm}$ ). This study demonstrated that, in case of rain, the load can increase easily of $100-200 \mathrm{~kg} / \mathrm{m}^{2}$. On the basis of these considerations, for our study, the absorption of $100 \mathrm{~kg} / \mathrm{m}^{2}$ of water in a deposit can increase the hazard area (area with probability greater than $5 \%$ of a loading equal to $300 \mathrm{~kg} / \mathrm{m}^{2}$ ) from 972 to $1660 \mathrm{~km}^{2}$, for the reference scenario.

\section{Competing interests}

The authors declare that they have no competing interests.

\section{Authors' contributions}

All the authors contributed in writing of the paper. The numerical simulation with HAZMAP were performed by GM and AC. All authors read and approved the final manuscript.

\section{Acknowledgments}

We thank Susanna Jenkins and an anonymous referee for their helpful suggestions. We also acknowledge the Editor Thomas Wilson for the time and effort spent in managing the paper. We thanks the Aeronautica Militare for producing radio-sounding data in Italy, and the University of Wyoming and NOAA where they can be freely downloaded. NCEP Reanalysis and 20th Century Reanalysis V2 data were provided by the NOAA/OAR/ESRL PSD, Boulder, Colorado, USA, from their Web site at http://www.esrl.noaa.gov/psd/. For the ERA-Interim data, we thanks the ECMWF. For the free software we thanks the UNIDATA Program Center for providing the netCDF and NCL libraries and the developers of the "Generic Mapping Tools" (GMT) and Gnuplot. Numerical simulations with HAZMAP-2.4.4 (cuda version) were performed on the Linux Cluster at Osservatorio Vesuviano funded by the Project PON-MIUR "VULCAMED" (Project PONa3_00278). This work was partially supported by the MED-SUV Project funded by the European Union (FP7 Grant Agreement n.308665). This work benefited of the agreement between Istituto Nazionale di Geofisica e Vulcanologia and the Italian Presidenza del Consiglio dei Ministri, Dipartimento della Protezione Civile (DPC). This paper does not necessarily represent DPC official opinion and policies.

\section{Author details}

${ }^{1}$ Istituto Nazionale di Geofisica e Vulcanologia, Osservatorio Vesuviano, Via Diocleziano 328, 80124 Napoli, Italy. ${ }^{2}$ Istituto Nazionale di Geofisica e Vulcanologia, Sezione di Bologna, Via Donato Creti 12, 40128 Bologna, Italy. 3 Istituto Nazionale di Geofisica e Vulcanologia, Osservatorio Etneo, P.zza Roma 2, 95125 Catania, Italy. ${ }^{4}$ Istituto Nazionale di Geofisica e Vulcanologia, Sezione di Pisa, Via della Faggiola 32, 56126 Pisa, Italy.

Received: 19 June 2015 Accepted: 25 February 2016

Published online: 08 March 2016

\section{References}

Andronico D, Calderoni G, Cioni R, Sbrana A, Sulpizio R, Santacroce R (1995) Geological map of Somma-Vesuvius volcano. Period Mineral 64(1-2):77-8 Andronico D, Cioni R (2002) Contrasting styles of Mount Vesuvius activity in the period between the Avellino and Pompeii Plinian eruptions, and some implications for assessment of future hazards. Bull Volcanol 64:372-91. doi:0.1007/s00445-002-0215-4

Aulinas M, Civetta L, Di Vito MA, Orsi G, Gimeno D, Férnandez-Turiel JL (2008) The "Pomici di mercato" Plinian eruption of Somma-Vesuvius: magma chamber processes and eruption dynamics. Bull Volcanol 70:825-40. doi:10.1007/s00445-007-0172-z

Armienti P, Macedonio G, Pareschi MT (1988) A numerical model for the simulation of tephra transport and deposition: Applications to May 18, 1980 Mount St, Helens eruption. J Geophys Res 93(B6):6463-76. doi:10.1029/JB093iB06p06463

Arastoopour H, Wang CH, Weil SA (1982) Particle-particle interaction force in a diluite gas-solid system. Chem Eng Sci 37(9):1379-86

Bagheri GH, Bonadonna C, Manzella I, Vonlanthen P (2015) On the characterization of size and shape of irregular particles. Powder Technol 270:141-53. doi:10.1016/j.powtec.2014.10.015

Barberi F, Cioni R, Santacroce R, Sbrana A, Vecci R (1989) Magmatic and phreatomagmatic phases in explosive eruptions of Vesuvius as deduced by grain-size and component analysis of the pyroclastic deposits. J Volcanol Geotherm Res 38:287-307. doi:10.1016/0377-0273(89)90044-9 
Barberi F, Macedonio G, Pareschi MT, Santacroce R (1990) Mapping the tephra fallout risk: an example from Vesuvius (Italy). Nature 344:142-4. doi:10.1038/344142a0

Barsotti S, Andronico D, Neri A, Del Carlo P, Baxter PJ, Aspinall WP, Hincks T (2010) Quantitative assessment of volcanic ash hazards for health and infrastructure at Mt, Etna (Italy) by numerical simulation. J Volcanol Geotherm Res 192(1/2):85-96. doi:10.1016/j.jvolgeores.2010.02.011

Barsotti S, Neri A, Cioni R, Mulas M, Mundula F (2015) Dynamics and tephra dispersal of Violent Strombolian eruptions at Vesuvius: insights from field data, wind reconstruction and numerical simulation of the 1906 event. Bull Volcanol. doi:10.1007/s00445-015-0939-6

Berrisford P, Dee D, Poli P, Brugge R, Fielding K, Fuentes M, Kållberg P, Kobayashi S, Uppala S, Simmons A (2011) The ERA-Interim archive. Technical Report Version 2.0, European Centre for Medium Range Weather Forecasts (ECMWF), Reading, UK

Bertagnini A, Landi P, Rosi M, Vigliargio A (1998) The Pomici di Base plinian eruption of Somma-Vesuvius. J Volcanol Geotherm Res 83:219-39. doi:10.1016/S0377-0273(98)00025-0

Bonadonna C, Biass S, Costa A (2015) Physical characterization of explosive volcanic eruptions based on tephra deposits: propagation of uncertainties and sensitivity analysis. J Volcanol Geotherm Res 296:80-100. doi:10.1016/j.jvolgeores.2015.03.009

Bonadonna C, Costa A (2012) Estimating volume of tephra deposits: a new simple strategy. Geology 40(5):415-8. doi:10.1130/G32769.1

Bonadonna C, Connor CB, Houghton BF, Connor L, Byrne M, Laing A, Hincks TK (2005) Probabilistic modeling of tephra dispersal: Hazard assessment of a multiphase rhyolitic eruption at Tarawera, New Zealand. J Geophys Res 110:03203. doi:10.1029/2003JB002896

Bonadonna C, Costa A (2013) Plume height, volume, and classification of volcanic explosive eruptions based on the Weibull function. Bull Volcanol 75(742):1-19. doi:10.1007/s00445-013-0742-1

Bonadonna C, Houghton B (2005) Total grain-size distribution and volume of tephra-fall deposits. Bull Volcanol 67:441-56. doi:10.1007/s00445004-0386-2

Bonadonna C, Macedonio G, Sparks RSJ (2002) Numerical modelling of tephra fallout associated with dome collapses and Vulcanian explosions: application to hazard assessment on Montserrat. In: Druitt TH, Kokelaar BP (eds). The Eruption of Soufrière Hills Volcano, Montserrat, from 1995 - 1999 Memoirs. Geol Soc, London Vol. 21. pp 517-37. doi:10.1144/ GSL.MEM.2002.021.01.23

Bonadonna C, Phillips JC (2003) Sedimentation from strong volcanic plumes. J Geophys Res 108(B7):2340. doi:10.1029/2002JB002034

Bonasia R, Capra L, Costa A, Macedonio G, Saucedo R (2011) Tephra fallout hazard assessment for a Plinian eruption scenario at Volcan de Colima (Mexico). J Volcanol Geotherm Res 203:11-22. doi:10.1016/j.jvolgeores. 2011.03.006

Bonasia R, Costa A, Folch A, Capra L, Macedonio G (2012) Numerical simulation of tephra transport and deposition of the 1982 El Chichon eruption and implications for hazard assessment. J Volcanol Geotherm Res 231-232:39-49. doi:10.1016/j.jvolgeores.2012.04.006

Capra L, Norini G, Groppelli G, Macías JL, Arce J (2008) Volcanic hazard zonation of the Nevado de Toluca volcano, méxico. J Volcanol Geotherm Res 176:469-84. doi:10.1016/j.jvolgeores.2008.04.016

Bonasia R, Macedonio G, Costa A, Mele D, Sulpizio R (2010) Numerical inversion and analysis of tephra fallout deposits from the 472 AD sub-Plinian eruption at vesuvius (Italy) through a new best-fit procedure. J Volcanol Geotherm Res 189:238-46. doi:10.1016/j.jvolgeores.2009.11.009

Cioni R, Bertagnini A, Santacroce R, Andronico D (2008) Explosive activity and eruption scenarios at Somma-Vesuvius (Italy): Towards a new classification scheme. J Volcanol Geotherm Res 178(3):331-46. doi:10.1016/j.jvolgeores. 2008.04.024

Cioni R, Levi S, Sulpizio R (2000) Apulian Bronze Age pottery as a long-distance indicator of the Avellino Pumice eruption (Vesuvius, Italy). Geological Society, London, Special Publications 171(1):159-77. doi:10.1144/GSL.SP. 2000.171.01.13

Cioni R, Longo A, Macedonio G, Santacroce R, Sbrana A, Sulpizio D, Andronico D (2003) Assessing pyroclastic fall hazard through field data and numerical simulations: Example from Vesuvius. J Geophys Res. 108(B2):2063-73. doi:10.1029/2001JB000642

Cioni R, Santacroce R, Sbrana A (1999) Pyroclastic deposits as a guide for reconstructing the multi-stage evolution of the Somma-Vesuvius caldera. Bull Volcanol 60(4):207-22. doi:10.1007/s004450050272
Carey SN, Sigurdsson H (1982) Influence of particle aggregation on deposition of distal tephra from the May 18, 1980, eruption of Mount St-Helens volcano. J Geophys Res 87(B8):7061-72. doi:10.1029/JB087iB08p07061

Compo GP, Whitaker JS, Sardeshmukh PD (2006) Feasibility of a 100 year reanalysis using only surface pressure data. Bull Amer Met Soc 87:175-90. doi:10.1175/BAMS-87-2-175

Compo GP, Whitaker JS, Sardeshmukh PD, Matsui N, Allan RJ, Yin X, Gleason BE, Vose RS, Rutledge G, Bessemoulin P, Bronnimann S, Brunet M, Crouthamel RI, Grant AN, Groisman PY, Jones PD, Kruk MC, Kruger AC, Marshall GJ, Maugeri M, Mok HY, Nordli O, Ross TF, Trigo RM, Wang XL, Woodruff SD, Worley SJ (2011) The Twentieth Century Reanalysis Project. Quarterly J Roy Met Soc 137:1-28. doi:10.1002/qj.776

Connor LJ, Connor C (2006) Inversion is the key to dispersion: understanding eruption dynamics by inverting tephra fallout. In: Mader HM, Coles SG, Connor CB, Connor LJ (eds). Statistics in Volcanology. Special Publication of IAVCEI. Geological Society, London Vol. 1. pp 231-42

Cornell W, Carey S, Sigurdsson H (1983) Computer simulation and transport of the Campanian Y-5 ash. J Volcanol Geotherm Res 17:89-109. doi:10.1016/0377-0273(83)90063-X

Costa A, Dell'Erba F, Di Vito MA, Isaia R, Macedonio G, Orsi G, Pfeiffer T (2009) Tephra fallout hazard assessment at the Campi Flegrei caldera (Italy). Bull Volcanol 71(3):259-73. doi:10.1007/s00445-008-0220-3

Costa A, Folch A, Macedonio G (2010) A model for wet aggregation of ash particles in volcanic plumes and clouds: I. Theoretical formulation. J Geophys Res. 115(B09201). doi:10.1029/2009JB007175

Costa A, Folch A, Macedonio G, Giaccio B, Isaia R, Smith VC (2012) Quantifying volcanic ash dispersal and impact from Campanian Ignimbrite super-eruption. Geophys Res Lett 39(L10310). doi:10.1029/2012GL051605

Costa A, Folch A, Macedonio G (2013) Density-driven transport in the umbrella region of volcanic clouds: Implications for tephra dispersion models. Geophys Res Lett 40:1-5. doi:10.1002/grl.50942

Costa A, Smith VC, Macedonio G, Matthews NE (2014) The magnitude and impact of the Youngest Toba Tuff super-eruption. Front Earth Sci 2(16):1-8. doi:10.3389/feart.2014.00016

Dellino P, Mele D, Bonasia R, Braia L, La Volpe R (2005) The analysis of the influence of pumice shape on its terminal velocity. Geophys Res Lett. 32(L21306). doi:10.1029/2005GL023954

DPC (2001) Proposta di aggiornamento. Aggiunte e varianti alle parti A3, B, C1 e C2 della Pianificazione Nazionale d'Emergenza dell'area Vesuviana, Presidenza del Consiglio dei Ministri, Dipartimento della Protezione Civile, Roma. http://www.protezionecivile.gov.it/resources/cms/documents/ 2001_aggiunte_e_varianti.pdf. Accessed 1 Mar 2016

DPC (2012) Scenari Eruttivi e Livelli di Allerta per II Vesuvio. Report of Gruppo di Lavoro A, Commissione nazionale incaricata di provvedere all'aggiornamento dei piani di emergenza dell'area vesuviana e flegrea per il rischio vulcanico, Presidenza del Consiglio dei Ministri, Dipartimento della Protezione Civile, Roma. http://www.protezionecivile.gov.it/ resources/cms/documents/Rapporto_finale_gruppo_lavoro_Vesuvio_ 2012_definitivo.pdf. Accessed 1 Mar 2016

DPC (2015) Vesuvio, mappa di delimitazione della "Zona Gialla". http://www. protezionecivile.gov.it/resources/cms/documents/mappa_zona_gialla. pdf. Accessed 1 Mar 2016

Folch A, Costa A, Durant A, Macedonio G (2010) A model for wet aggregation of ash particles in volcanic plumes and clouds: II. Model application. J Geophys Res 115(B09202). doi:10.1029/2009JB007176

Fiorillo F, Wilson RC (2004) Rainfall induced debris flows in pyroclastic deposits, Campania (southern Italy). Eng Geol 75:263-89

Ganser GH (1993) A rational approach to drag prediction of spherical and nonspherical particles. Powder Technol 77(2):143-52. doi:10.1016/00325910(93)80051-B

Hill BE, Connor CB, Jarzemba MS, La Femina PC, Navarro M, Strauch W (1998) 1995 eruption of Cerro Negro volcano Nicaragua, and risk assessment for future eruptions. Geol Soc Am Bull 110:1231-41. doi:10.1130/0016-7606 (1998) $110<1231:$ EOCNVN>2.3.CO;2

James MR, Lane SJ, Gilbert JS (2003) Density, construction, and drag coefficient of electrostatic volcanic ash aggregates. J Geophys Res 108:2435. doi:10.1029/2002JB002011

Jenkins SF, Barsotti S, Hincks TK, Neri A, Phillips JC, Sparks RSJ, Sheldrake T, Vougioukalakis $G$ (2015) Rapid emergency assessment of ash and gas hazard for future eruptions at Santorini Volcano, Greece. J Appl Volcanol 4(16). doi:10.1186/s13617-015-0033-y 
Kalnay E, Kanamitsu M, Kister R, Collins W, Deaven D, Gandin L, Iredell M, Saha S, G W, Woollen J, Zhu Y, Chelliah M, Ebisuzaki M, Higgins W, Janowiak J, Mo KG, Ropelewski C, Wang J, Leetmaa A, Reynolds R, Jenne R, Joseph D (1996) The NCEP/NCAR 40-years reanalysis project. Bull Amer Meteor Soc 77(3):437-70. doi:10.1175/1520-0477(1996)077<0437:TNYRP>2.0.CO;2. Data available at http://www.esrl.noaa.gov/psd/data/reanalysis/. Accessed 1 Mar 2016

Macedonio G, Costa A, Longo A (2005) A computer model for volcanic ash fallout and assessment of subsequent hazard. Comput Geosci 31:837-45. doi:10.1016/j.cageo.2005.01.013

Macedonio G, Costa A, Folch A (2008) Ash fallout scenarios at Vesuvius: Numerical simulations and implications for hazard assessment. J Volcanol Geotherm Res 178(3):366-77. doi:10.1016/j.jvolgeores.2008.08.014

Macedonio G, Costa A (2012) Brief Communication: Rain effect on the load of tephra deposits. Nat Hazards Earth Syst Sci 12:1229-33. doi:10.5194/ nhess-12-1229-2012

Macedonio G, Pareschi MT, Santacroce R (1988) A numerical simulation of the Plinian fall phase of the 79 AD eruption of Vesuvius. J Geophys Res 93(B12):14817-27. doi:10.1029/JB093iB12p14817

Macedonio G, Pareschi MT, Santacroce R (1990) Renewal of volcanic activity at Vesuvius: tephra fallout. J Volcanol Geotherm Res 40(4):327-42. doi:10.1016/0377-0273(90)90112-S

Mannen K (2006) Total grain size distribution of a mafic subplinian tephra, TB-2, from the 1986 Izu-Oshima eruption, Japan: An estimation based on a theoretical model of tephra dispersal. J Volcanol Geotherm Res 155:1-17. doi:10.1016/j.jvolgeores.2006.02.004

Mele D, Sulpizio R, Dellino P, La Volpe L (2011) Stratigraphy and eruptive dynamics of a pulsating Plinian eruption of Somma-Vesuvius: the Pomici di Mercato (8900 years BP). Bull Volcanol 73:257-78. doi:0.1007/s00445010-0407-2

Neri A, Aspinall WP, Cioni R, Bertagnini A, Baxter PJ, Zuccaro G, Andronico D, Barsotti S, Cole PD, Esposti Ongaro T, Hincks TK, Macedonio G, Papale P, Rosi M, Santacroce R, Woo G (2008) Developing an Event Tree for probabilistic hazard and risk assessment at Vesuvius. J Volcanol Geotherm Res 178(3):397-415. doi:10.1016/j.jvolgeores.2008.05.014

Pfeiffer T, Costa A, Macedonio G (2005) A model for the numerical simulation of tephra fall deposits. J Volcanol Geotherm Res 140(4):273-94. doi:10.1016/j.jvolgeores.2004.09.001

Pierson TC (1986) Flow behavior of channelled debris flows, Mount St, Helens. Washington. In: Abrahams AD (ed). Hillslope Processes. Allen \& Unwin, Boston, Mass. pp 269-96

Pincus R, Rew R (2010) The NetCDF Fortran 90 Interface Guide. User guide, Unidata Program Center, University Corporation for Atmospheric Research. http://www.unidata.ucar.edu. Accessed 1 Mar 2016

Pyle DM (1989) The thickness, volume and grainsize of tephra fall deposits. Bull Volcanol 51(1):1-15. doi:10.1007/BF01086757

Regione Campania (2015) Delimitazione della Zona Gialla del Piano di Emergenza della'area Vesuviana. Delibera della Giunta Regionale n. 29 del 09/02/2015. http://www.lavoripubblici.regione.campania.it. Accessed 1 Mar 2016

Rew R, Davis G, Emmerson H, Hartnett E, Haimbigner D (2010) The NetCDF Users Guide. University Corporation for Atmospheric Research. http:// www.unidata.ucar.edu. Accessed 1 Mar 2016

Rolandi G, Barrella AM, Borrelli A (1993) The 1631 eruption of Vesuvius. J Volcanol Geotherm Res 58(1-4):183-201. doi:10.1016/0377-0273(93) 90107-3

Rolandi G, Munno R, Postiglione I (2004) The AD 472 eruption of the Somma volcano. J Volcanol Geotherm Res 129:291-319. doi:10.1016/S0377-0273 (03)00279-8

Rose WI, Durant AJ (2009) Fine ash content of explosive eruptions. J Volcanol Geotherm Res 186:32-9. doi:10.1016/j.jvolgeores.2009.01.010

Rosi M, Santacroce R (1983) The A.D, 472 "Pollena" Eruption: volcanological and petrological data from this poorly known Plinian-type event at Vesuvius. J Volcanol Geotherm Res 17(1-4):249-71. doi:10.1016/03770273(83)90071-9

Rosi M, Principe C, Vecci R (1993) The 1631 Vesuvius eruption: A reconstruction based on historical and stratigraphical data. J Volcanol Geotherm Res 58(1-4):151-82. doi:10.1016/0377-0273(93)90106-2

Rosi M, Santacroce R, Sheridan MF (1987) Volcanic hazard. In: Santacroce R (ed). Somma-Vesuvius. Quaderni de La Ricerca Scientifica. Consiglio Nazionale delle Ricerche, Roma Vol. 114(8). pp 197-220
Santacroce R, Cioni R, Marianelli P, Sbrana A, Sulpizio R, Zanchetta G, Donahue DJ, Joron JL (2008) Age and whole rock-glass compositions of proximal pyroclastics from the major explosive eruptions of Somma-Vesuvius: A review as a tool for distal tephrostratigraphy. J Volcanol Geotherm Res 107:1-18. doi:10.1016/j.jvolgeores.2008.06.009

Scaini S, Folch A, Navarro M (2012) Tephra hazard assessment at Concepción Volcano, Nicaragua. J Volcanol Geotherm Res 219-220:41-51. doi:10.1016/j.jvolgeores.2012.01.007

Scollo S, Folch A, Costa A (2008) A parametric and comparative study of different tephra fallout models. J Volcanol Geotherm Res 176(2):199-211. doi:10.1016/j.jvolgeores.2008.04.002

Scollo S, Coltelli M, Bonadonna C, Del Carlo P (2013) Tephra hazard assessment at Mt, Etna (Italy). Nat Hazards Earth Syst Sci 13:3221-233. doi:10.5194/nhess-13-3221-2013

Sieron K, Capra L, Rodríguez-Elizararrás S (2014) Hazard assessment at San Martín volcano based on geological record, numerical modeling, and spatial analysis. Nat Hazards 70:275-97. doi:0.1007/s1 1069-013-0807-7

Spence RJS, Kelman I, Baxter PJ, Zuccaro G, Petrazzuoli S (2005) Residential building and occupant vulnerability to tephra fall. Nat Hazards Earth Syst Sci 5:477-94. doi:10.5194/nhess-5-477-2005

Suzuki T (1983) A theoretical model for dispersion of tephra. In: Shimozuru D, Yokoyama I (eds). Arc Volcanism: Physics and Tectonics. Terra Scientific Publishing Company (TERRAPUB), Tokyo. pp 93-113

Todesco M, Neri A, Esposti Ongaro T, Papale P, Macedonio G, Santacroce R, Longo A (2002) Pyroclastic flow hazard at Vesuvius from numerical modeling. I, Large-scale dynamics. Bull Volcanol 64(3-4):155-77. doi:10.1007/s00445-001-0189-7

Volentik CMA, Bonadonna C, Connor CB, Connor LJ, Rosi M (2010) Modeling tephra dispersal in absence of wind: Insights from the climactic phase of the 2450 BP Plinian eruption of Pululagua volcano (Ecuador). J Volcanol Geotherm Res 193:117-36. doi:10.1016/j.jvolgeores.2010.03.011

Walker GPL (1971) Grain size characteristics of pyroclastic deposits. J Geol 79(6):696-714

Wilson L, Huang TC (1979) The influence of shape on the atmospheric settling velocity of volcanic ash particles. Earth Planet Sci Lett 44(2):311-24. doi:10.1016/0012-821X(79)90179-1

Wilson L, Walker GPL (1987) Explosive volcanic eruptions-VI, Ejecta dispersal in Plinian eruptions: the control of eruption conditions and atmospheric properties. Geophys J R Astron Soc 89:657-79

Zuccaro G, Cacace F, Spence RJS, Baxter PJ (2008) Impact of explosive eruption scenarios at Vesuvius. J Volcanol Geotherm Res 178:416-53. doi:10.1016/ j.jvolgeores.2008.01.005

\section{Submit your manuscript to a SpringerOpen ${ }^{\odot}$ journal and benefit from:}

- Convenient online submission

Rigorous peer review

- Immediate publication on acceptance

- Open access: articles freely available online

- High visibility within the field

- Retaining the copyright to your article

Submit your next manuscript at springeropen.com 